\title{
Analisis Bauran Pemasaran (Marketing mix) Jasa Penginapan Berbasis Syariah Di Hotel Sofyan Inn Srigunting Bogor.
}

\author{
Ika Suryono Djunaid \\ Manajemen Perhotelan, Sekolah Tinggi Pariwisata Bogor
}

\begin{abstract}
ABSTRAK
Latar belakang penelitian ini adalah adanya fenomena pariwisata syariah yang merupakan konsep yang mengintegrasikan nilai-nilai syariah ke dalam kegiatan-kegiatan pariwisata dengan menyediakan fasilitas dan layanan yang sesuai dengan ketentuan syariah tidak terkecuali hotel syariah sebagai salah satu bentuk fasilitas layanan dalam pariwisata syariah yang memberikan bentuk layanan hospitality. Penelitian ini bertujuan untuk mengetahui sejauh mana strategi pemasaran jasa berbasis syariah di Hotel Sofyan Inn Srigunting Bogor. Penelitian ini menggunakan metode kuantitatif deskriptif, dengan menyebarkan kuesioner kepada para tamu untuk mengetahui bagaimana pelayanan yang di rasakan oleh para tamu di hotel Sofyan Inn Srigunting Bogor. Kesimpulan dari penelitian ini adalah bauran pemasaran jasa berbasis syariah di Hotel Sofyan Inn Srigunting Bogor sudah berjalan dengan sangat efektif. Apabila di tinjau dari keseluruhan adalah baik dengan nilai rata-rata 405. Namun perlu adanya sedikit perbaikan mengenai varian tipe kamar untuk menambah kepuasan tamu di Hotel Sofyan Inn Srigunting Bogor.
\end{abstract}

Kata kunci :

Bauran Pemasaran, Hotel Syariah,

\begin{abstract}
The background of this research is the existence of shariah tourism phenomenon which is a concept that integrates syariah values into tourism activities by providing facilities and services in accordance with the provisions of sharia is no exception sharia hotels as one form of service facilities in sharia tourism that gives form hospitality service. This study aims to determine the extent to which the strategy of marketing services based on Shariah Hotel Sofyan Inn Srigunting Bogor. This research uses descriptive quantitative method, by distributing questionnaires to the guests to find out how the service felt by the guests at Sofyan Inn Srigunting Bogor hotel. The conclusion of this research is the marketing mix of syariah-based services at Hotel Sofyan Inn Srigunting Bogor has been running very effectively. If the review of the overall is good with an average value of 405. But there needs to be a little improvement about the variant type of room to increase guest satisfaction at Sofyan Inn Srigunting Hotel Bogor.
\end{abstract}

\section{Keywords:}

Marketing Mix, Sharia Hotel 


\section{PENDAHULUAN}

\section{Latar Belakang Penelitian}

Perkembangan bisnis dan teknologi yang semakin tinggi memudahkan manusia dalam melaksanakan aktivitas wisata. Setiap usaha bisnis pariwisata berlomba-lomba menghasilkan suatu tujuan untuk menghasilkan profit yang sebesar-besarnya dengan memanfaatkan sumber daya alam dan menyajikannya dalam bentuk produk pariwisata. Indonesia sebagai negara kepulauan terbesar di dunia memiliki potensi pariwisata yang tinggi sehingga mampu menjadi daya tarik bagi wisatawan domestik maupun internasional. Perkembangan dunia pariwisata Indonesia dapat dilihat dari jumlah wisatawan mancanegara ke Indonesia yang terus meningkat setiap tahunnya. Menurut Badan Pusat Statistik pada tahun 2010, mencatat terjadi kenaikan jumlah kedatangan wisatawan mancanegara di Indonesia pada Tahun 2002 - 2009 sebanyak 52.56 \% / tahun.

Pada 30 Oktober 2013, Presiden Indonesia me-launching Pariwisata Syariah Indonesia di JIEXPO Kemayoran, Jakarta Pusat (Kementerian Pariwisata dan Ekonomi Kreatif Republik Indonesia, 2013) sejalan dengan ini pemerintah juga mencanangkan untuk meningkatkan lagi jumlah restoran, hotel, dan tempat lainnya yang bersertifikat halal.

Korespondensi Penulis

Ika Suryono Djunaid, SSt.Par, MM.Par koko_aufklarung@rocketmail.com
Bedasarkan survey (sumber UNWTO, 2013) dari organisasi survey turis dunia (United World Tourism Organization, 2013), Malaysia menjadi satu-satunya negara Asia Tenggara yang masuk dalam kategori negara yang paling sering dikunjungi turis dunia menempati posisi sembilan pada tahun 2011 dan posisi sepuluh pada tahun 2012 dari seluruh negara di dunia.

Pariwisata syariah adalah pariwisata yang menikmati segala kekayaan alam dan tempat wisata di setiap negara namun dibalut dalam esensi syariah dan tidak hanya ditargetkan pada wisawatan muslim saja, namun terbuka untuk semua kalangan karena pariwisata syariah bukanlah pariwisata religi (Islam) tapi menikmati berbagai dengan konsep syariah yang memberikan manfaat tidak hanya kepada pengelola bisnis, namun manfaatnya bisa dirasakan oleh penikmat wisata dan lingkungan sekitar dan terjamin keberlangsungannya. Esensi syariah tidak hanya mengkomsusi makanan dan minuman dalam konteks halal. Halal disini juga dijelaskan mengapa makanan tersebut dikatakan halal dan layak dikomsumsi. Perusahaan asal Singapura, Crescentrating memberikan suatu data tentang evolusi industry syariah (sumber Crescent Rating, 2012).

Salah satu kota di Indonesia yang sedang dikembangkan kegiatan pariwisata syariahnya adalah kota Bogor. Kota Bogor memiliki potensi wisata yang luar biasa, keberadaannya yang sangat strategis merupakan potensi pengembangan pembangunan, 
pertumbuhan ekonomi dan pelayanan, pusat industri nasional, komunikasi dan pariwisata. Kedekatan kota Bogor dengan Jakarta sebagai salah satu pintu masuk utama wisatawan merupakan kekuatan dalam pengembangan pariwisata. Jumlah wisatawan yang berkunjung pada tahun 2009 adalah 1.566 .856 pengunjung menurut (master plan pariwisata kota Bogor, 2010).

Sebagai penununjang Ibukota, Bogor mulai memperbaiki bisnis syariahnya mulai dari perusahaan makanan cepat saji maupun jasa penginapan akan lebih dikemas secara apik dan berlabel halal agar semakin di kenal lebih syar'i dan lebih terjamin keamanan dan kehalalannya.

Hotel Sofyan Inn Srigunting Bogor yang bergerak di industri pariwisata syariah menjadi sasaran dalam penelitian ini. Alasan mengapa perusahaan ini menjadi pilihan untuk dilakukannya penelitian dan penyusunan perencanaan pemasaran adalah karena keunikan yang ditawarkan Hotel sofyan Inn Bogor selain menjadi hotel syariah pertama yang ada di Indonesia sejak 1996. Hal tersebut menjadikan penompang ekonomi syariah yang sedang di issukan di era sekarang. keputusan para pengunjung dalam menentukan pilihannya banyak pertimbangan, seperti di era sekarang kebanyakan dari pengunjung sering mencermati terlebih dahulu sebelum menginap di dalam sebuah hotel ,berbandingan produk, harga, dan tempat. Fenomena tersebut menjadikan tantangan bagi manajemen hotel syariah sofyan inn srigunting bogor. Bauran pemasaran terdiri atas sesuatu yang dapat di lakukan perusahaan untuk mempengaruhi permintaan, kemungkinan itu dapat di kelompokkan menjadi 4p : Product (produk), Price (harga), Promotion (promosi), Place (tempat). Dari hasil observasi di tempat penelitian Hotel sofyan inn srigunting bogor tidak menjual produk seperti kamar ataupun atribut fisik seperti hotel pada umumnya, namun Hotel Sofyan Inn Srigunting Bogor menjual gaya hidup (lifestyle) syariah, dimana para tamu hotel tidak hanya menikmati produk atau jasa perhotelan semata, namun merasakan suasana (ambience) Islami yang tercipta dari pertama kali masuk lobby hotel sampai check out keluar dari lingkungan hotel, Dengan adanya perbedaan itu maka akan menambahkan tiga bauran pemasyaran (marketing mix) yang terdiri dari people (orang), Physical evidence (fasilitas fisik) dan Process (Proses).

Berdasarkan uraian di atas, maka pembahasan ini layak di angkat dan di kaji melalui penelitian dengan judul:

\section{" Analisa Bauran Pemasaran (Marketing mix)}

\section{JASA PENGINAPAN BERBASIS SYARIAH DI}

\section{HOTEL SOFYAN INN SRIGUNTING BOGOR”}

\section{Batasan Masalah}

Agar penulisan karya tugas akhir ini tidak menyimpang dari isi secara keseluruhannya, penulis hanya membatasi permasalahan tentang strategi pemasaran hotel yang berbasis syariah, melingkupi bauran pemasaran (marketing mix), yaitu : Product 
(produk), Harga (Price), Tempat (Place), Promosi (Promotion), Orang (People), Proses (Process), Fasilitas Fisik (Psychal Evidance).

\section{Rumusan Masalah}

Bertolak dari latar belakang yang telah diuraikan, maka yang jadi masalah pokok dalam penelitian ini adalah apakah berpengaruh analisa bauran pemasaran (marketing mix) jasa penginapan berbasis syariah yang dilaksanakan di Hotel Sofyan Inn Srigunting Bogor sudah sesuai dengan keinginan pelanggan?

\section{LANDASAN TEORI}

\section{Kerangka Teori}

Hotel

Kata Hotel mulai dipakai sejak abad ke 18 di London, Inggris. Pada saat itu kata hotel adalah "garni" sebuah rumah besar yang dilengkapi dengan sarana tempat menginap/tinggal untuk penyewaan secara harian, mingguan atau bulanan. Kata hotel sendiri merupakan perkembangan dari bahasa Perancis. Hotel berasal dari kata latin: "hostel" dan mulai dikenal di masyarakat pada tahun 1797. Ada beberapa definisi hotel berdasarkan berbagai pendapat, di antaranya :

Menurut ( Rumekso, 2002 : 2 ) hotel adalah bangunan yang menyediakan kamarkamar untuk menginap para tamu, makanan dan minuman, serta fasilitas-fasilitas lain yang diperlukan dan dikelola secara profesional untuk mendapatkan keuntungan dan hotel adalah suatu bentuk akomodasi yang dikelola secara komersil, disediakan bagi setiap orang untuk memperoleh pelayanan dan penginapan berikut makan dan minum. Adapun menurut ( SK Menteri Perhubungan No. Pm. 10/Pw. 301/Phb. 77 ) hotel merupakan perusahaan yang menyediakan jasa dalam bentuk akomodasi serta menyediakan hidangan dan fasilitas lainnya dalam hotel untuk umum yang memenuhi syarat kenyamanan dan bertujuan komersil dalam jasa tersebut kembali diperkuat oleh ( SK. Menteri Perhubungan No. 241/11/1970 ).

Karakteristik bisnis perhotelan menurut Boham dan Suwithi (2008) produk bisnis perhotelan mempunyai empat karakteristik khusus, yaitu produk nyata (tangible), tidak nyata (intangible), bersifat "perishable" dan "non perishable". Produk yang bersifat nyata antara lain kamar, makanan, minuman, kolam renang dan sebagainya. Produk yang bersifat tidak nyata, antara lain keramah-tamahan, kenyamanan, keindahan, keamanan dan sebagainya. Produk bersifat perishable artinya bahwa produk tersebut hanya bisa dijual saat ini adalah produk tidak tahan lama yang dapat disimpan di gudang contohnya kamar hotel, bahan makanan segar yang tidak dapat disimpan seperti sayur-sayuran. Produk yang bersifat non perishable misalnya minuman keras, soft drink, perlengkapan tamu (guest supply and amenities). Bisnis hotel mempunyai tujuan yaitu mendapatkan pendapatan seoptimal mungkin melalui pemenuhan kebutuhan dan keinginan tamu (guest need \& wants). Kepuasan tamu menjadi tujuan pelayanan untuk membentuk 
citra hotel yang baik dan sekaligus menjamin keberadaan hotel dalam jangka panjang.

\section{Hotel Syariah}

Hotel syariah adalah hotel yang menyediakan jasa pelayanan penginapan, makanan, dan minuman, serta jasa lainnya bagi umum, di kelola secara komersial serta memenuhi ketentuan persyaratan yang di tetapkan pemerintah, industri, dan syariah (Sofyan Hotel 2015). Menurut Sabri (2010) ketentuan-ketentuan syariah yang berupa larangan yang harus di jauhi dalam hukum mu'amalah, termasuk di dalam nya usaha perhotelan adalah adanya sesuatu yang melanggar syariah, membahayakan, penipuan, dan bersifat meragukan. Penjelasannya adalah sebagai berikut:

1. Dalam hotel syariah tidak memproduksi, memperdagangkan, menyediakan, atau menyewakan produk atau jasa yang secara keseluruhan maupun sebagiannya yang dilarang dalam ketentuan syariah, seperti makanan yang mengandung unsur babi, minuman khamar, perjudian, praktek perzinahan, dan sebagainya yang mengandung unsur najis dan di haramkan oleh syariat.

2. Dalam hotel syariah tidak mengandung adanya unsur kedhaliman, membahayakan, kemungkaran, kemaksiatan maupun kesesatan yang terlarang dalam kaidah syariah baik secara langsung maupun tidak langsung.
3. Dalam hotel syariah tidak ada pula unsur penipuan, kecurangan kebohongan, ketidakjelasan (gharar), resiko yang berlebihan dan membahayakan.

4. Dalam hotel syariah sebuah transaksi harus di lakukan berdasarkan jasa atau produk yang nyata, benar-benar ada, dan tidak ada sesuatu yang bersifat meragukan yang dapat merusak keabsahan transaksi.

Terpenuhinya kebutuhan masyarakat akan hotel syariah, memberikan dampak yang disebut dengan mashlahah pada proses pemenuhan kebutuhan tempat tinggal sementara di suatu daerah. Menurut P3EI UII (2013) menyatakan bahwa mashlahah adalah segala bentuk keadaan baik material maupun non material, yang mampu meningkatkan kedudukan manusia sebagai makhluk yang paling mulia. Menurut Al-Ghazali, kesejahteraan atau mashlahah dasar kehidupan manusia terdiri dari lima hal yakni, agama (din), jiwa (nafs), akal (aql), keturunan (nash) dan harta (maal). Pada hotel konvensional tidak memberikan dampak pada mashlahah karena mereka menjalankan bisnis tidak bertujuan untuk melindungi kelima hal tersebut.

Hotel syariah memiliki standar khusus untuk menyediakan makanan atau minuman yang telah terjamin kehalalannya. Sesuai dengan standar penyediaan makanannya, proses pembuatannya hingga cara menghidangkan makanan. Hal ini sesuai dengan ajaran islam yang terdapat pada ayat Al-Qur'an surat AnNahl ayat 115 berikut: 


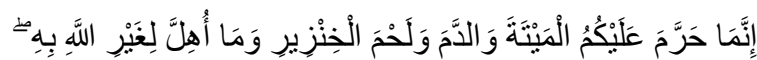

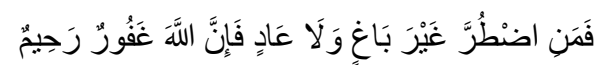
Artinya: "Sesungguhnya Allah hanya mengharamkan atasmu (memakan) bangkai, darah, daging babi dan apa yang disembelih dengan menyebut nama selain Allah; tetapi barangsiapa yang terpaksa memakannya dengan tidak menganiaya dan tidak pula melampaui batas, maka sesungguhnya Allah Maha Pengampun lagi Maha Penyayang”

Sesuai ayat tersebut bahwa hotel syariah tidak menyediakan makanan yang mengandung unsur babi atau minuman keras dan sejenisnya. Hotel syariah hanya menyediakan makanan dan minuman berlabel halal dari MUI.

Ada beberapa perbedaan kriteria usaha hotel syariah dengan hotel konvensional. Melihat kebutuhan konsumen yang semakin beragam, hotel syariah menjadi sebuah rujukan penting yang dijadikan salah satu tujuan untuk menginap. Umumnya hotel syariah masih berstatus bintang tiga yang dimana memberikan spiritual benefit yang tidak ditawarkan oleh hotel kovensional. Sehingga keuntungan spiritual ini menjadi daya tarik baru pada industri hotel yang menjadi tujuan konsumen kelas menengah muslim. Dorongan terhadap kebutuhan fasilitas ibadah dan makanan minuman halal mendorong pertumbuhan hotel syariah diberbagai daerah destinasi wisata. Di hotel syariah, konsumen mendapatkan pelayanan atau perlakuan sesuai dengan ketentuan syariah. Semua pelayan hotel syriah wajib menyapa dengan sapaan salam agama Islam, dan para pelayan perempuan diwajibkan mengenakan hijab.

Menurut Yuswohady (2014) tumbuhnya hotel syariah tidak lepas dari keinginan konsumen kelas menengah muslim untuk mendapatkan fasilitas menginap yang sesuai dengan ajaran agama islam. Ada beberapa perbedaan pada hotel syariah dan hotel konvensional.

\section{PERBEDAAN HOTEL SYARIAH DAN KONVENSIONAL.}

\begin{tabular}{|c|l|l|}
\hline $\begin{array}{c}\text { Perbedaan Hotel } \\
\text { syariah dan Hotel } \\
\text { Konvensional }\end{array}$ & \multicolumn{1}{|c|}{ Hotel Syariah } & \multicolumn{1}{|c|}{ Hotel Konvensional } \\
\hline Penerimaan Tamu & $\begin{array}{l}\text { Tidak memperkenankan tamu bukan } \\
\text { muhrim menginap pada satu kamar, } \\
\text { KTP wajib di perlihatkan }\end{array}$ & $\begin{array}{l}\text { Tidak melarang tamu bukan muhrim } \\
\text { untuk menginap dalam satu kamar, } \\
\text { KTP wajib di perlihatkan }\end{array}$ \\
\hline Standar Pelayanan & $\begin{array}{l}\text { Seragam pakaian hotel di wajibkan } \\
\text { menutup auratnya,memberikan } \\
\text { salam dalam agama islam. Tidak }\end{array}$ & $\begin{array}{l}\text { Seragam pakaian semua pelayan hotel } \\
\text { mencerminkan corporate identity. } \\
\text { Pelayan tidak }\end{array}$ \\
\hline
\end{tabular}




\begin{tabular}{|c|c|c|}
\hline & $\begin{array}{l}\text { segan menegur tamu yang bukan } \\
\text { muhrim. }\end{array}$ & $\begin{array}{l}\text { menggunakan hijab dan } \\
\text { mengucapkan salam universal. }\end{array}$ \\
\hline $\begin{array}{l}\text { Fasilitas Kamar } \\
\text { Tidur }\end{array}$ & $\begin{array}{l}\text { Adanya pemisahan lantai ruang } \\
\text { tidur laki-laki dan perempuan } \\
\text { single, dan juga tamu yang } \\
\text { membawa keluarga }\end{array}$ & $\begin{array}{l}\text { Tidak ada pemisahan antara lantai } \\
\text { ruang tidur laki-laki dan perempuan } \\
\text { sinle dan tamu keluarga }\end{array}$ \\
\hline Makanan-Minuman & $\begin{array}{l}\text { Menyediakan makanan dan } \\
\text { minuman yang berlabel halal dari } \\
\text { MUI dan tidak menyediakan bar } \\
\text { maupun minuman beralkohol. }\end{array}$ & $\begin{array}{l}\text { Menyediakan kebutuhan makanan- } \\
\text { minuman halal dan non-halal dan juga } \\
\text { menyediakan bar dan minuman } \\
\text { beralkohol. }\end{array}$ \\
\hline Fasilitas Ibadah & $\begin{array}{l}\text { Terdapat fasilitas ibadah, sajadah, } \\
\text { mukena dan Al-Qur'an di setiap } \\
\text { kamar, dan mushola atau masjid di } \\
\text { area hotel. Menyediakan petunjuk } \\
\text { arah kiblat di setiap kamar hotel. }\end{array}$ & $\begin{array}{l}\text { Umumnya tidak menyediakan } \\
\text { fasilitas ibadah di kamar. Hanya ada } \\
\text { mushola di atau petunjuk arah kiblat } \\
\text { dan itu hanya sedikit yang ada di hotel } \\
\text { konvensional. }\end{array}$ \\
\hline Fasilitas Toilet & $\begin{array}{l}\text { Menyediakan air yang cukup atau } \\
\text { toilet shower untuk kegunaan yang } \\
\text { kebih bersih. }\end{array}$ & $\begin{array}{l}\text { Menyediakan toilet kering dengan } \\
\text { fasilitas tisu. }\end{array}$ \\
\hline Fasilitas Kebugaran & $\begin{array}{l}\text { Menyediakan fasilitas kebugaran } \\
\text { dengan memisah antara laki-laki dan } \\
\text { perempuan dalam satu ruangan. }\end{array}$ & $\begin{array}{l}\text { Menyediakan fasilitas kebugaran } \\
\text { dengan menyatukan laki-laki dan } \\
\text { perempuan dalam satu ruangan. }\end{array}$ \\
\hline Fasilitas Pijat/Spa & $\begin{array}{l}\text { Menyediakan fasilitas pijat dimana } \\
\text { laki-laki hanya boleh dipijat oleh } \\
\text { laki-laki,begitupun sebaliknya. }\end{array}$ & $\begin{array}{l}\text { Menyediakan fasilitas pijat untuk } \\
\text { pengunjung hotel baik laki-laki dan } \\
\text { perempuan. }\end{array}$ \\
\hline Alarm Ibadah & $\begin{array}{l}\text { Menyediakan fasilitas alarm } \\
\text { pengingat waktu shalat tiba. }\end{array}$ & $\begin{array}{l}\text { Tidak menyediakan alarm untuk } \\
\text { melaksanakan ibadah. }\end{array}$ \\
\hline
\end{tabular}

Sumber: Yuswohady, 2014

\section{Manajemen Pemasaran}

Manajemen Pemasaran merupakan salah satu kegiatan penting yang perlu dilakukan perusahaan untuk meningkatkan usaha dan menjaga kelangsungan hidup perusahaan tersebu. Disamping kegiatan pemasaran perusahaan juga perlu mengkombinasikan fungsi-fungsi dan menggunakan keahlian mereka agar perusahaan berjalan dengan baik. Dalam hal ini perlu diketahui beberapa definisi pemasaran. Menurut 
Kotler pemasaran adalah suatu proses sosial dan manajerial yang didalamnya individu dan kelompok mendapatkan apa yang mereka butuhkan dan inginkan dengan menciptakan, menawarkan dan mempertukarkan produk yang bernilai dengan pihak lain" (1997:8). Dan pemasaran menurut (Wy. Stanton 1997) adalah sesuatu yang meliputi seluruh sistem yang berhubungan dengan tujuan untuk merencanakan dan menentukan harga sampai dengan mempromosikan dan mendistribusikan barang dan jasa yang bisa memuaskan kebutuhan pembeli aktual maupun potensial.

Begitupun menurut (Boyd, Walker, Larreche, 1998) pemasaran adalah suatu proses analisis, perencanaan, implementasi, koordinasi dan pengendalian program pemasaran yang meliputi kebijakan produk, harga, promosi, dan distribusi dari produk, jasa, dan ide yang ditawarkan untuk menciptakan dan meningkatkan pertukaran manfaat dengan pasar sasaran dalam upaya pencapaian tujuan organisasi.

Beberapa definisi maupun pengertian mengenai pemasaran diantaranya adalah :

1. Pemasaran adalah kegiatan manusia yang diarahkan untuk memenuhi kebutuhan dan keinginan melalui proses pertukaran. (Philip Kotler:1992)

2. Pemasaran adalah sebagai suatu proses sosial dan managerial yang membuat individu dan kelompok memperoleh apa yang mereka butuhkan dan inginkan lewat penciptaan dan

pertukaran timbal balik produk dan nilai dengan orang lain. (Philip Kotler dan Amstrong 2001)

3. Pemasaran adalah suatu sistem total dari kegiatan bisnis yang dirancang untuk merencanakan, menentukan harga, promosi dan mendistribusikan barang- barang yang dapat memuaskan keinginan dan mencapai pasar sasaran serta tujuan perusahaan (Swasta dan irawan 2013)

4. Pemasaran adalah suatu sistem keseluruhan dari kegiatan-kegiatan usaha yang ditujukan untuk merencanakan, menentukan harga, mempromosikan dan mendistribusi-kan barang dan jasa yang dapat memuaskan kebutuhan baik kepada pembeli maupun pembeli potensial (William J Stanton).

5. Wikipedia, Dalam wikipedia menyatakan bahwa pemasaran adalah suatu proses penyusunan komunikasi yang terpadu \& tujuannya untuk memberikan informasi tentang barang atau jasa yang diperjualbelikan yang kaitannya untuk memuaskan keinginan \& kebutuhan masyarakat.

6. Kamus Besar Bahasa Indonesia (KBBI) Th.2008, Pemasaran ialah proses; cara; perbuatan dalam memasarkan barang dagangan; perihal menyebarluaskan di tengah-tengah masyarakat pada umumnya.

Strategi Bauran Pemasaran (Marketing Mix) 
Dalam pemasaran terdapat strategi pemasaran yang disebut dengan bauran pemasaran (marketing mix) yang memiliki peranan penting dalam mempengaruhi konsumen agar dapat membeli suatu produk atau jasa yang di tawarkan oleh perusahaan. Elemen-elemen bauran pemasaran terdiri dari semua variabel yang dapat di kontrol perusahaan untuk dapat memuaskan para konsumen.

Sebelum mengurai satu per satu, berikut ini adalah bauran pemasaran (marketing mix) menurut para ahli:

1. Bauran pemasaran (marketing mix) menurut (Buchari alma, 2007:130) adalah strategi mencampur kegiatan-kegiatan marketing, agar dicari kombinasi maximal sehingga dapat mendatangkan hasil yang memuaskan.

2. Begitupun menurut (Zeithaml dan Bitner, 2008:48) Bauran pemasaran (marketing mix) adalah elemen - elemen organisasi perusahaan yang dapat di kontrol oleh perusahaan dalam melakukan komunikasi dengan tamu dan untuk memuaskan tamu.

3. Sedangkan bauran pemasaran (marketing mix) menurut Kotler dan Armstrong (1997) adalah perangkat pemasaran yang baik meliputi produk, penentuan harga, promosi, distribusi, digabungkan untuk menghasilkan respon yang di inginkan pasar sasaran.

Dari ketiga pengertian marketing mix menurut para ahli di atas dapat disimpulkan bahwa bauran pemasaran merupakan alat pemasaran yang baik yang berada dalam suatu perusahaan, dimana perusahaan mampu mengendalikannya agar dapat mempengaruhi respon pasar sasaran.

Dalam bauran pemasaran terdapat seperangkat alat pemasaran yang dikenal dengan marketing mix 4P, yaitu product (produk), price (harga), place (tempat atau saluran distribusi), dan promotion (promosi), sedangkan dalam pemasaran jasa memiliki beberapa alat pemasaran tambahan seperti people (orang), physical evidence (fasilitas fisik), dan process (proses), sehingga dikenal dengan marketing $\operatorname{mix} 7 \mathrm{P}$.

Dari definisi diatas dapat diartikan bahwa bauran pemasaran merupakan variablevariabel terkendali yang digabungkan untuk menghasilkan tanggapan yang diharapkan dari pasar sasaran. Dan untuk usaha jasa terdapat 7 unsur marketing mix (Marketing Mix-7p) yaitu: Produk (Product), Harga (Price), Tempat (Place), Promosi (Promotion), Orang (Partisipant/people), Proses (Process), Dan Fasilitas Fisik (Physical Evidence).

a) Produk (Product)

Produk merupakan elemen penting dalam sebuah program pemasaran. Strategi produk dapat mempengaruhi strategi pemasaran lainnya. Pembelian sebuah produk bukan hanya sekedar untuk memiliki produk tersebut tetapi juga untuk memenuhi kebutuhan dan keinginan konsumen.

b) Harga (Price) 
Menurut Monroe (2005) menyatakan bahwa harga merupakan pengorbanan ekonomis yang dilakukan pelanggan untuk memperoleh produk atau jasa. Selain itu harga salah satu faktor penting konsumen dalam mengambil keputusan untuk melakukan transaksi atau tidak (Engel, Blackwell dan Miniard, 1996).

Harga dikatakan mahal, murah atau biasabiasa saja dari setiap individu tidaklah harus sama, karena tergantung dari persepsi individu yang dilatar belakangi oleh lingkungan kehidupan dan kondisi individu (Schifman and Kanuk, 2001).

c) Promosi (Promotion)

Promosi adalah kegiatan mengkomunikasikan informasi dari penjual kepada konsumen atau pihak lain dalam saluran penjualan untuk mempengaruhi sikap dan perilaku. Melalui periklanan suatu perusahaan mengarahkan komunikasi persuasif pada pembeli sasaran dan masyarakat melalui media-media yang disebut dengan media massa seperti koran, majalah, tabloid, radio, televise dan direct mail (Baker, 2000:7). Media promosi yang dapat digunakan pada bisnis ini antara lain (1) Periklanan, (2) Promosi penjualan, (3) Publisitas dan hubungan masyarakat, dan (4) Pemasaran langsung. Penentuan media promosi yang akan digunakan didasarkan pada jenis dan bentuk produk itu sendiri.

d) Saluran Distribusi/Tempat (Place)
Kotler (2000: 96) menyatakan bahwa "Saluran distribusi terdiri dari seperangkat lembaga yang melakukan segala kegiatan (Fungsi) yang digunakan untuk menyalurkan produk dan status pemiliknya dari produsen ke konsumen". Dari definisi diatas dapat diartikan bahwa saluran distribusi suatu barang adalah keseluruhan kegiatan atau fungsi untuk memindahkan produk disertai dengan hak pemiliknya dari produsen ke konsumen akhir atau pemakai industri. Distribusi berkaitan dengan kemudahan memperoleh produk di pasar dan tersedia saat konsumen mencarinya. Distribusi memperli hatkan berbagai kegiatan yang dilakukan perusahaan untuk menjadikan produk atau jasa dipe roleh dan tersedia bagi konsumen sasaran.

e) Partisipan/Orang (People)

Yang dimaksud partisipan disini adalah karyawan penyedia jasa layanan maupun penjualan, atau orang-orang yang terlibat secara langsung maupun tidak langsung dalam proses layanan itu sendiri, misalnya dalam jasa kecantikan : diantaranya adalah para reception, dokter, dan beauty therapis.

f) Proses (Process)

Proses adalah kegiatan yang menunjukkan bagaimana pelayanan diberikan kepada konsumen selama melakukan pembelian barang. Pengelola usaha melalui front liner sering menawarkan berbagai macam bentuk pelayanan untuk tujuan menarik konsumen. Fasilitas jasa konsultasi gratis, pengiriman 
produk, credit card, card member dan fasilitas layanan yang berpengaruh pada image perusahaan.

g) Lingkungan Fisik/Fasilitas (Physical Evidence)

Sarana fisik (Physical Evidence), merupakan hal nyata yang turut mempengaruhi keputusan konsumen untuk membeli dan menggunakan produk atau jasa yang ditawarkan. Unsur yang termasuk dalam sarana fisik antara lain lingkungan atau

\section{Kerangka Konseptual}

Sumber: Kotler dan Armstrong (1997)

\section{Tujuan Dan Manfaat Penelitian}

\section{Tujuan Penelitian}

a. Untuk mengetahui strategi apa yang di gunakan oleh hotel Sofyan Inn Srigunting Bogor dalam melakukan pemasaran produk jasa penginapan berbasis syariah yang dimilikinya.

b. Untuk mengetahui dan menjelaskan penerapan dari bauran pemasaran produk jasa penginapan berbasis syariah yang di bangunan fisik, peralatan, perlengkapan, logo, warna dan barang-barang lainnya.

Dari ketujuh elemen marketing mix tersebut yang merupakan kunci sukses bagi sebuah usaha (jasa yang bertempat/salon/spa/warnet) diantaranya adalah kelengkapan produk layanan yang siap ditawarkan (one stop service), lokasi yang strategis, keramahan dan efektivitas pelayanan, tempat parkir yang memadai, dan fasilitas tain

Strategi Pemasaran Syariah

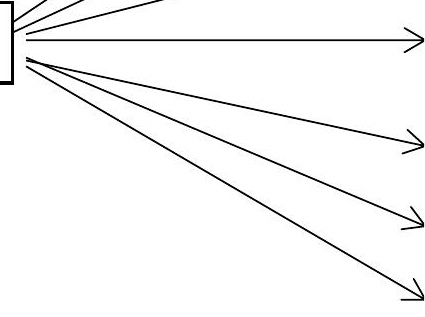

terapkan mampu mempengaruhi perkembangan jumlah pelanggan pada hotel Sofyan Inn Srigunting Bogor.

\section{Manfaat Penelitian}

a. Sebagai bahan masukan untuk menjadi pertimbangan bagi manajemen perusahaan, khususnya mengenai pemasaran jasa hotel Sofyan Inn Srigunting Bogor dalam meningkatkan hunian kamar, frekuensi pemakaian Meeting Room, dan restoran.

b. Sebagai bahan informasi yang diharapkan berguna untuk memperkarya 
pengetahuan.

d. Bagi Pembaca, sebagai tambahan referensi bacaan tentang strategi-strategi pemasaran dalam meningkatkan tingkat occupancy hotel.

\section{METODE PENELITIAN}

\section{Gambaran Umum Obyek Penelitian}

Hotel Sofyan Inn Srigunting Bogor Bogor merupakan salah satu Hotel bintang 2+ atau lebih cenderung ke butik hotel di Bogor. Hotel Sofyan Inn Srigunting Bogor ini mengusung konsep bisnis hotel syariah, Hotel Sofyan Inn Srigunting Bogor tak lagi menyediakan minuman keras, klub malam hingga selektif dalam menerima tamu. Dengan mengusung konsep syariah, maka di setiap kamar di Hotel Sofyan Inn Srigunting Bogor selalu di lengkapi perlengkapan alat shalat di setiap kamarnya. Hotel Sofyan Inn Srigunting Bogor mempunyai interior campuran modern dan tradisonal, sehingga interior Sofyan Inn Srigunting Bogor terlihat elegan dan homey.

Hotel Sofyan Inn Srigunting Bogor terletak di jalan Pangrango No. 19, Bogor, membuat Sofyan Inn Srigunting Bogor sangat strategis, karena berada di jantung kota Bogor. Hotel Sofyan Inn Srigunting Bogor Di kelilingi aneka sentra oleh-oleh khas dari Bogor yang sangat terkenal, Seperti Pizza bakar, Apple Pie, Macaroni Panggang, Klapert Tart,dan masih wisata kuliner yang lain nya. Hotel Sofyan Inn Srigunting Bogor juga dekat dengan Kebun
Raya Bogor, Istana Bogor, Pusat perbelanjaan Botani Square, dan perkantoran. Akses dari Jakarta hanya 30 menit sampai Hotel Sofyan Inn Srigunting Bogor melalui Tol Jagorawi. 15 Menit ke Stasiun Bogor, 15 menit terminal Baranang Siang, 10 menit pusat perbelanjaan Botani Square dan 10 menit dari pusat perbelanjaan Jambu Dua Plaza.

Adapun visi dan misi Hotel Sofyan Inn Srigunting Bogor adalah :

Visi : Menjadikan Hotel Sofyan Inn Srigunting Bogor sebagai hotel terbaik dengan konsep syariah nya dan menjadi pilihan utama bagi keluarga dan instansi baik pemerintah maupun swasta di kota Bogor dan sekitarnya.

Misi :

1. Memberikan pelayan secara maksimal guna memenuhi kepuasan pelanggan.

2. Menyediakan fasilitas yang menunjang. Seperti : Room,meeting room yang cukup memadai, wifi, Restaurant

Hotel Sofyan Inn Srigunting Bogor mempunyai 30 kamar, terdiri dari tipe kamar Superior Room Deluxe Dan executive Room, memiliki fasilitas yang cukup baik didalam kamar, seperti : Safety Box, Air Conditional, Electric Door Locks, Room Service 24 Hours, Telephone System, Large Working Desk, Shower, Bathroom Amenities, Free Wifi, Cofee Maker, dan TV Cable. Hotel Sofyan Inn Srigunting Bogor memiliki Fasilitas Penunjang lainnya, seperti : 3 ruang meeting, Restaurant, Free parking area, dan Mushola. 
Awalnya bangunan Hotel Sofyan Inn Srigunting Bogor merupakan bangunan wisma atau guest house hotel ini didirikan oleh $\mathrm{Ny}$. $\mathrm{Hj}$. Tuti Juwati dengan nama Wisma Srigunting pada tahun 1996 di Bogor. Untuk memenuhi kebutuhan dan permintaan tamu kemudian mengetahui bahwa Indonesia merupakan negara dengan penduduk mayoritas muslim terbesar di dunia, dengan jumlah penduduk beragama Islam sebanyak 209 juta jiwa. Sebagai negara dengan mayoritas penduduk beragama Islam, fasilitas, dan infrastuktur pariwisata yang ada Indonesia telah dianggap cukup ramah pada para wisatawan muslim, sehingga pemilik wisma berfikir untuk mengambil keputusan dan mengubah bisnisnya kedalam bisnis penginapan syariah, Pada tahun 2010 pemilik wisma ini memutuskan bergabung dalam salah satu management bisnis perhotelan yang mengusung konsep bisnis penginapan syariah terbesar di Indonesia yakni PT. Sofyan Hotel Tbk pada tahun 2010 tepatnya bulan November wisma Srigunting melakukan renovasi dan pada Tahun 2012 merubah namanya menjadi Hotel Sofyan Inn Srigunting Bogor, yang kini memiliki fasilitas 30 kamar dan 3 meeting room dan restorant dengan mengusung konsep bisnis penginapan syariah tentu akan menunjang wisatawan baik wisata islami maupun bisnis syariah sebagai tempat singgah dengan konsep syariah di Bogor.

Sejak mengusung konsep syariah peningkatan hunian semakin meningkat dan terbukti salah satu hotel yang sudah menerapkan prinsip syariah di Indonesia dan telah memenangkan World Halal Travel Award 2015 yang diselenggarakan di Dubai adalah Hotel Sofyan Inn Srigunting Bogor yang terletak di wilayah Kota Bogor yang sudah memiliki beberapa cabang di Indonesia (Sofyan Hotel 2015). Hotel Sofyan Inn Srigunting Bogor kini diposisikan sebagai hotel dengan landasan bisnis syariah yang pertama di Indonesia yang mendapatkan sertifikat dari Dewan Syariah Nasional (DSN) Majelis Ulama Indonesia (MUI) Nomor NK 11/KS 001/W PEK/2012 dan Nomor B-459/DSN-MUI/XII/2012 tentang Pengembangan dan Sosialisasi Pariwisata Syariah perlu dilakukan pengaturan mengenai penyelenggaraan Usaha Hotel Syariah. Hotel sofyan merupakan hotel syariah pertama yang telah mencatatkan sahamnya di bursa efek (Rezeki 2011). Kini hotel Sofyan Inn Srigunting Bogor Bogor memulai melebarkan bisnisnya dengan membuka wisma dengan konsep syariah di jln Heulang yang akan membuat bisnis syariahnya semakin bertambah dan berkembang untuk menunjang kebutuhan konsumen.

\section{Metode Pengumpulan Data}

Metode penelitian yang digunakan dalam penyusun tugas akhir ini adalah kuantitatif dengan melakukan observasi secara langsung dengan melakukan penyebaran kuesioner, yang bertujuan mengetahui aspek efektivitas strategi pemasaran jasa penginapan berbasis syariah di hotel Sofyan Inn Srigunting Bogor.

a. Observasi. 
Menurut Jogiyanto (2008) observasi merupakan teknik atau pendekatan untuk mendapatkan data primer dengan cara mengamati langsung obyek datanya.

b. Kuesioner

Menurut Suharsimi Arikunto, Kuesioner/angket adalah daftar pertanyaan yang diberikan kepada orang lain yang bersedia memberikan respon sesuai dengan permintaan pengguna. Dengan demikian angket/kuesioner adalah daftar pertanyaan yang disiapkan oleh peneliti dimana tiap pertanyaannya berkaitan dengan masalah penelitian. Angket tersebut pada akhirnya diberikan kepada responden untuk dimintakan jawaban.

c. Tinjauan Pustaka

Seperti dinyatakan oleh Leedy (1997) bahwa semakin banyak seorang peneliti mengetahui, mengenal dan memahami tentang penelitian-penelitian yang pernah dilakukan sebelumnya (yang berkaitan erat dengan topik penelitiannya), semakin dapat dipertanggung jawabkan caranya meneliti permasalahan yang dihadapi. Walaupun demikian, sebagian penulis (usulan penelitian atau karya tulis) menganggap tinjauan pustaka merupakan bagian yang tidak penting sehingga ditulis "asal ada" saja atau hanya untuk sekedar membuktikan bahwa penelitian (yang diusulkan) belum pernah dilakukan sebelumnya. Pembuktian keaslian penelitian tersebut sebenarnya hanyalah salah satu dari beberapa kegunaan tinjauan pustaka. Kelemahan lain yang sering pula dijumpai adalah dalam penyusunan, Penstrukturan atau pengorganisasian tinjauan pustaka. Banyak penulisan tinjauan pustaka yang mirip resensi buku (dibahas buku per buku, tanpa ada kaitan yang bersistem) atau mirip daftar pustaka (hanya menyebutkan siapa penulisnya dan di pustaka mana ditulis, tanpa membahas apa yang ditulis). Berdasar kelemahankelemahan yang sering dijumpai di atas, tulisan ini berusaha untuk memberikan kesegaran pengetahuan tentang cara-cara penulisan tinjauan pustaka yang lazim dilakukan. Cakupan tulisan ini meliputi empat hal, yaitu: (a) kegunaan, (b) organisasi tinjauan pustaka, (c) kaitan tinjauan pustaka dengan daftar pustaka, dan (d) cara pencarian bahan-bahan pustaka, terutama dengan memanfaatkan teknologi informasi.

\section{Populasi dan Sampel}

Populasi dalam penelitian ini adalah orangorang yang pernah menginap di Hotel Sofyan Inn Srigunting Bogor. Populasi ini bersifat heterogen yang dapat dilihat dari beragamnya usia, jenis kelamin, dan pendidikan.

Penelitian ini mengambil sampel tamu yang yang pernah menginap di Hotel Sofyan Inn Srigunting Bogor. Untuk menentukan ukuran sampel penelitian dari populasi tersebut dapat digunakan rumus 15 atau 20 kali variabel bebas (Joseph F. Hair, 1998), jadi akan di dapat hasil sebagai berikut: $20 \times 5$ (jumlah variabel bebas) 
$=100$. Jadi, berdasarkan perhitungan diatas diperoleh jumlah sampel yang digunakan dalam penelitian ini adalah sebanyak 100 responden.

\section{Teknik Pengolahan Data}

Untuk teknik kuantitatif pengolahan datanya adalah menggunakan observasi dan melakukan penyebaran kuesioner, meminta para responden pengunjung di Hotel Sofyan Inn Srigunting Bogor untuk mengisi kuesioner. Teknik pengolahan data yang dilakukan penulis adalah teknik pengolahan data menggunakan statistik deskriptif untuk mencari beberapa nilai yaitu nilai rata-rata (mean), nilai tengah (median) dan nilai yang sering muncul (modus).

Dalam penelitian ini Penulis menggunakan skala likert sebagai berikut :

1. Sangat Tidak Setuju,

2. Tidak Setuju

3. Netral

4. Setuju dan

5. Sangat Setuju.

\section{HASIL PENELTIAN DAN PEMBAHASAN}

\section{Karakteristik Demografis Responden}

\section{Profil Responden}

Karakteristik demografi responden pada penelitian ini dibedakan menurut jenis kelamin, usia, pekerjaan dan pendapatan. a. Berdasarkan jenis kelamin

Berdasarkan jenis kelamin dari 100 responden maka didapat data sebagai berikut :

\section{Karakteristik Berdasarkan Jenis Gender Responden}

\begin{tabular}{c|c}
\hline Gender & Jumlah Responden \\
\hline Laki - laki & 53 \\
\hline Perempuan & 47 \\
\hline Total & $\mathbf{1 0 0}$ \\
\hline
\end{tabular}

Sumber : Olah Data Hasil Kuesioner, 2018

Berdasarkan Tabel Jenis Gender dapat diketahui bahwa tanggapan responden terhadap kuesioner Tentang Analisa Bauran pemasaran (Marketing mix) jasa penginapan berbasis syariah di hotel Sofyan Inn Srigunting Bogor berdasarkan gender responden adalah berjenis kelamin pria sejumlah 53 orang (53\%) sedangkan sisanya berjenis kelamin wanita yaitu sebanyak 47 orang (47\%).

\section{Diagram Berdasarkan Gender Responden}

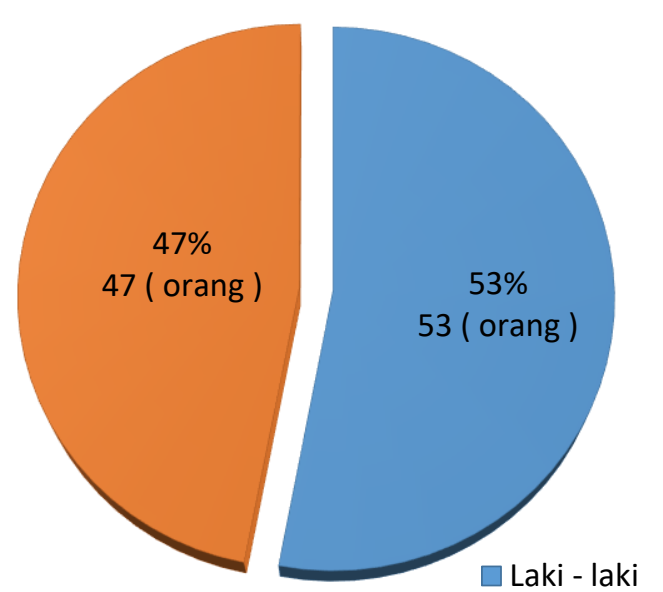


b. Berdasarkan Usia Responden

Berdasarkan usia responden dari 100 responden maka didapat data sebagai berikut :

\section{Karakteristik Berdasarkan Usia Responden}

\begin{tabular}{c|c}
\hline Usia & $\begin{array}{c}\text { Jumlah } \\
\text { Responden }\end{array}$ \\
\hline 15 - 19 Tahun & 0 \\
\hline $20-29$ Tahun & 41 \\
\hline $30-39$ Tahun & 59 \\
\hline $40-49$ Tahun & 0 \\
\hline$>$ 50 Tahun & 0 \\
\hline Total & $\mathbf{1 0 0}$ \\
\hline
\end{tabular}

Sumber : Olah Data Hasil Kuesioner, 2018

Berdasarkan Tabel Usia Responden dapat diketahui bahwa tanggapan responden terhadap kuesioner tentang Analisa Bauran pemasaran (Marketing mix) jasa penginapan berbasis syariah di hotel Sofyan Inn Srigunting Bogor berdasarkan usia responden adalah 20-29 tahun sejumlah 41 orang $(41 \%)$ sedangkan sisanya berusia 30-39 tahun yaitu sebanyak 59 (Lima Puluh Sembilan) orang (59\%).

\section{Diagram Berdasarkan Usia Responden}


c. Berdasarkan Pendidikan Responden

Berdasarkan Pendidikan Responden dari 100 responden maka didapat data sebagai berikut :

\section{Karakteristik Berdasarkan Pendidikan}

\section{Responden}

Sumber : Olah Data Hasil Kuesioner, 2018

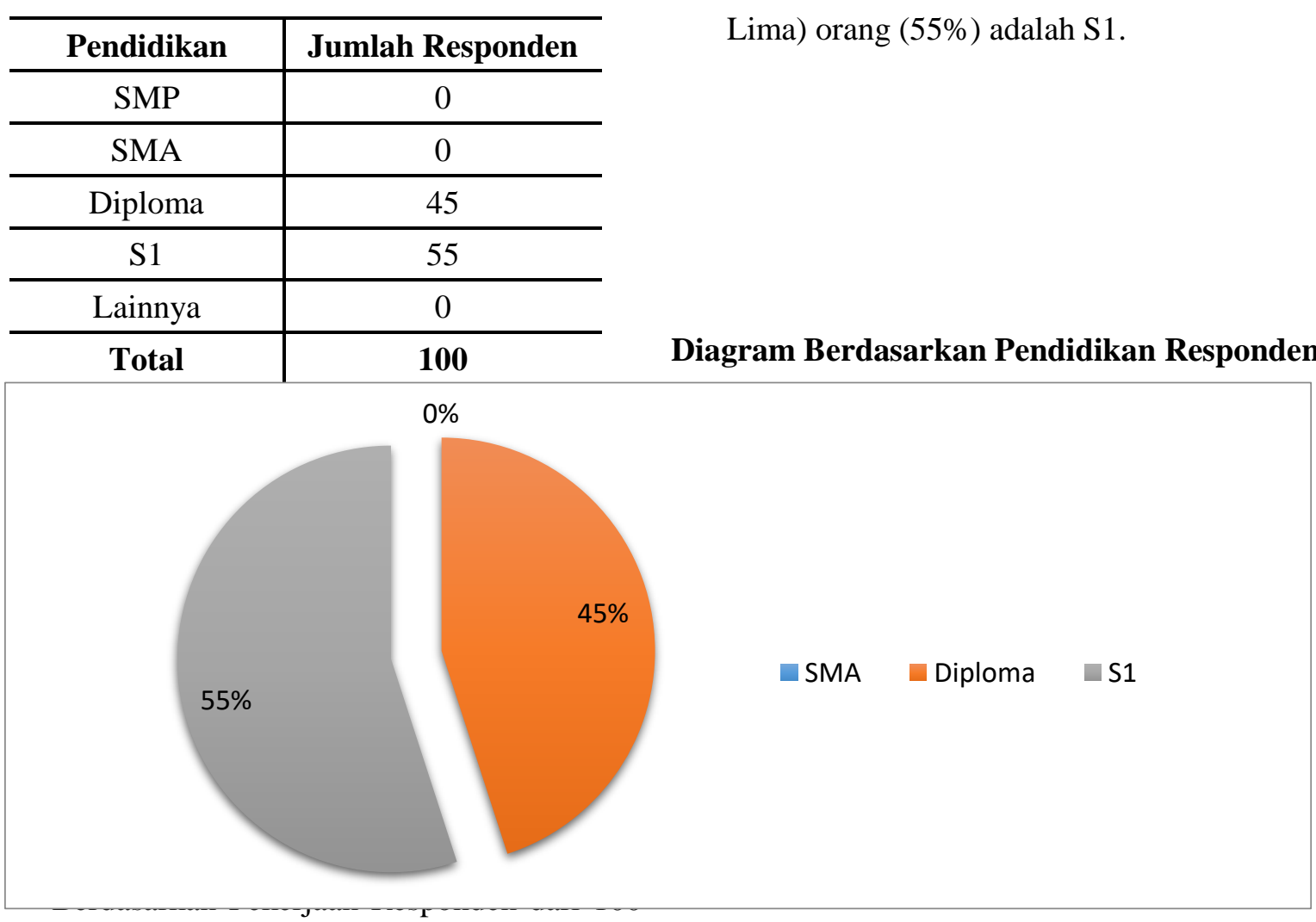

responden maka didapat data sebagai berikut :
Berdasarkan Tabel Pendidikan Responden dapat diketahui bahwa tanggapan responden terhadap kuesioner Tentang Analisa bauran pemasaran (Marketing mix) jasa penginapan berbasis syariah di Hotel Sofyan Inn Srigunting Bogor untuk tingkat pendidikan responden adalah 45 (Empat Puluh Lima) orang (45\%) dengan pendidikan diploma dan 55 (Lima Puluh Lima) orang (55\%) adalah S1. 


\section{Karakteristik Berdasarkan Pekerjaan Responden}

\begin{tabular}{c|c}
\hline Asal & Jumlah Responden \\
\hline Bogor & 37 \\
\hline Luar Bogor & 63 \\
\hline Total & $\mathbf{1 0 0}$ \\
\hline
\end{tabular}

Sumber : Olah Data Hasil Kuesioner, 2018

Berdasarkan Tabel Pekerjaan

Responden dapat diketahui bahwa tanggapan responden terhadap kuesioner Tentang Analisa bauran pemasaran (Marketing Mix) jasa penginapan berbasis syariah di Hotel Sofyan Inn Srigunting Bogor untuk tingkat pekerjaan responden adalah 38 (Tiga puluh delapan) orang (38\%) adalah seorang PNS, sedangkan sebagiannya 35 (Tiga Puluh Lima) orang (35\%) adalah karyawan swasta dan 27 (Dua Puluh Tujuh) orang (27\%) adalah Industri.

\section{Diagram Berdasarkan Pekerjaan Responden}

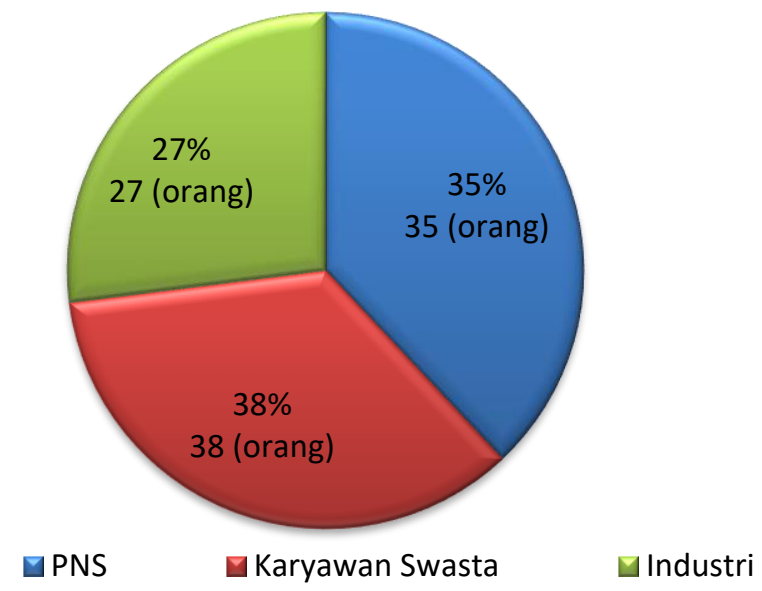

e. Berdasarkan Asal Responden

Berdasarkan Asal Responden dari 100 responden maka didapat data sebagai berikut :

\begin{tabular}{c|c}
\hline Pekerjaan & Jumlah Responden \\
\hline PNS & 38 \\
\hline Swasta & 35 \\
\hline Industri & 27 \\
\hline Pensiunan & 0 \\
\hline Lainnya & 0 \\
\hline Total & $\mathbf{1 0 0}$ \\
\hline
\end{tabular}

Sumber : Olah Data Hasil Kuesioner, 2018

Berdasarkan Tabel Asal Responden dapat diketahui bahwa tanggapan responden

\section{Karakteristik Berdasarkan Asal Responden}


terhadap kuesioner Tentang Anilisa bauran pemasaran (Marketing Mix) jasa penginapan berbasis syariah di Hotel Sofyan Inn Srigunting Bogor dapat di lihat dari kota asal responden adalah 37 (Tiga Puluh Tujuh) orang (37\%) bertempat tinggal di Bogor, sedangkan sebagiannya 63 (Enam Puluh Tiga) orang (63\%) berasal dari luar Bogor.

\section{Diagram Berdasarkan Asal Responden}

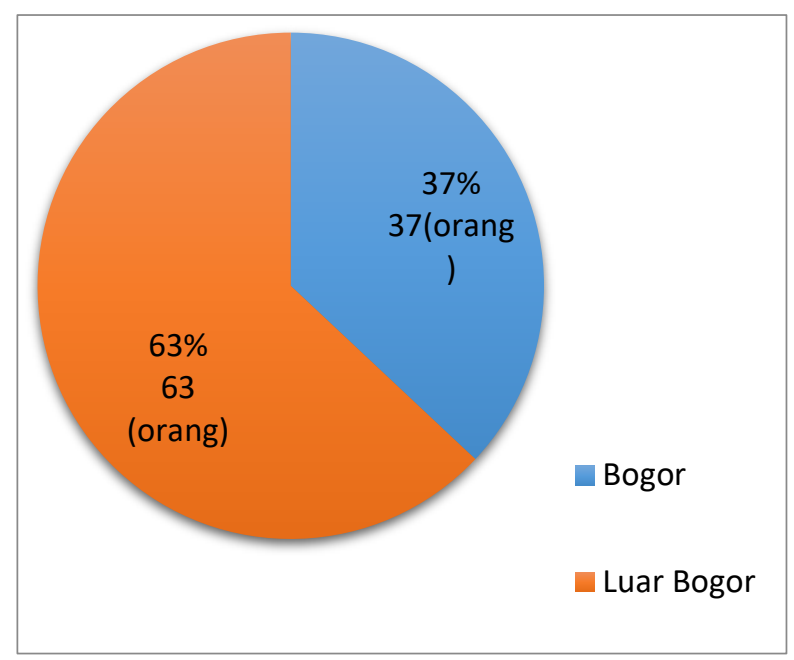

f. Berdasarkan Pendapatan Responden

Berdasarkan Pendapatan Responden dari 100 responden maka didapat data sebagai berikut :

\section{Karakteristik Berdasarkan Pendapatan} Responden

\begin{tabular}{c|c}
\hline Pendapatan & Jumlah Responden \\
\hline 1-2 Juta & 0 \\
\hline $2-3$ juta & 0 \\
\hline $3-4$ juta & 56 \\
\hline $4-5$ juta & 44 \\
\hline >5 juta & 0 \\
\hline Total & $\mathbf{1 0 0}$ \\
\hline
\end{tabular}

Sumber : Olah Data Hasil Kuesioner, 2018
Berdasarkan Pendapatan Responden dapat diketahui bahwa tanggapan responden terhadap kuesioner Tentang Analisa bauran pemasaran(marketing kix) jasa penginapan berbasis syariah di Hotel Sofyan Inn Srigunting Bogor dapat di lihat dari pendapatan responden adalah 56 (Lima Puluh Enam) orang (56\%) berpendapatan 3-4 juta, sedangkan sebagiannya 44 (Empat Puluh Empat) orang (44\%) berpendapatan 4-5 juta. 


\section{Diagram Berdasarkan Pendapatan Responden}

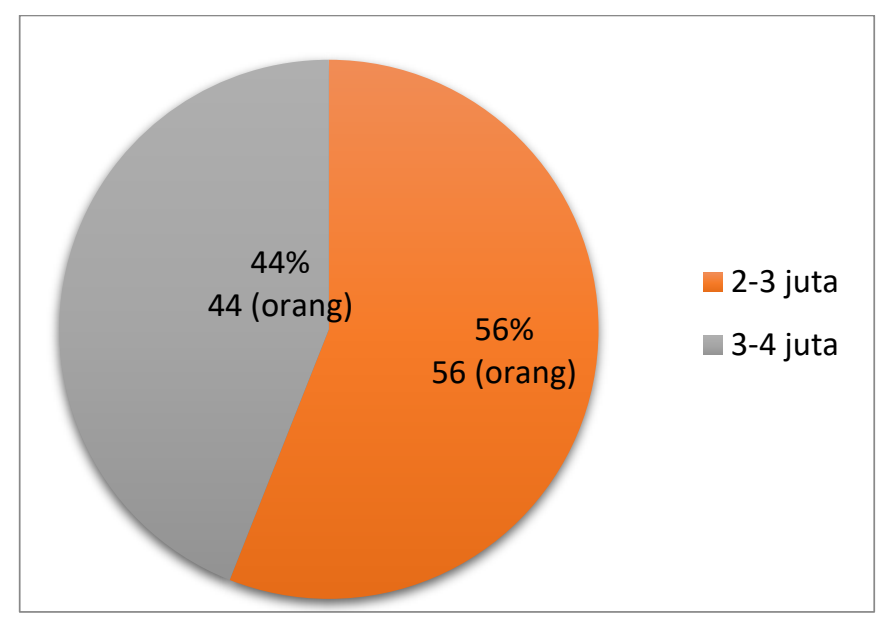

Penerapan Analisa Bauran Pemasaran (Marketing mix) Jasa Penginapan Berbasis Syariah Di Hotel Sofyan Inn Srigunting Bogor

Pada sub bab ini, akan dijelaskan mengenai hasil dari pertanyaan - pertanyaan yang diajukan kepada para tamu Hotel Sofyan Inn Srigunting Bogor mengenai Fasilitas atau produk yang di dapat selama menginap di hotel yang berbasis syariah di hotel Sofyan Inn Srigunting Bogor. Hal - hal yang penting dalam Analisa Bauran Pemasaran (Marketing mix) jasa penginapan berbasis syariah yang ada dan berlaku pada hotel tersebut, sehingga dapat dilakukan dengan baik dan benar sesuai konsep yang di usung.

Aspek yang ditanyakan di dalam kuesioner yang diberikan kepada tamu Hotel Sofyan Inn Srigunting Bogor, berisikan tentang produk (Product), Promosi (Promotion), Harga (Price), Tempat (Place), Orang (People), Proses
(Process), Fasilitas Fisik (Psychal Evidance) yang diberikan hotel tersebut. sehingga dapat diketahui apakah para tamu merasa terpenuhi kebutuhannya dalam menggunakan jasa penginapan yang berbasis syariah.

\section{Kuesioner Penilaian Produk Jasa Penginapan Berbasis Syariah Di Hotel Sofyan Inn Srigunting Bogor}

Berdasarkan data yang tercantum dalam kuesioner penerapan Analisa Bauran Pemasaran (Marketing mix) jasa penginapan syariah dari 100 responden mengenai penilaian yang diambil dari para pengunjung hotel yang merasakan produk syariah di Hotel Sofyan Inn Srigunting Bogor yang diperoleh data sebagai berikut.

\section{a. Penilaian Terhadap Hotel Syariah Menyediakan Berbagai Tipe Kamar Yang Sesuai Dengan Kebutuhan}

Berdasarkan data yang didapat melalui penyebaran kuesioner terhadap 
para pengunjung di Hotel Sofyan Inn

Srigunting Bogor dengan jumlah 100 orang mengenai penilaian terhadap hotel syariah menyediakan berbagai tipe kamar yang sesuai dengan kebutuhan.

\section{Penilaian Responden}

Tentang Hotel Syariah Menyediakan Berbagai Tipe Kamar Yang Sesuai Dengan Kebutuhan

\begin{tabular}{|c|c|c|c|c|c|c|}
\hline \multirow[b]{2}{*}{ Responden } & \multicolumn{5}{|c|}{ Sikap } & \multirow[b]{2}{*}{ Skor } \\
\hline & $\begin{array}{c}\text { Sangat tidak } \\
\text { setuju }\end{array}$ & $\begin{array}{l}\text { Tidak } \\
\text { Setuju }\end{array}$ & Netral & Setuju & $\begin{array}{l}\text { Sangat } \\
\text { Setuju }\end{array}$ & \\
\hline 8 & & & & & $\checkmark$ & $8 \times 5=40$ \\
\hline 70 & & & & $\checkmark$ & & $70 \times 4=280$ \\
\hline 18 & & & $\checkmark$ & & & $18 \times 3=54$ \\
\hline 3 & & $\checkmark$ & & & & $3 \times 2=6$ \\
\hline 1 & $\checkmark$ & & & & & $1 \times 1=1$ \\
\hline \multicolumn{6}{|c|}{ Total } & 381 \\
\hline Persentase & $1 \%$ & $3 \%$ & $18 \%$ & $70 \%$ & $8 \%$ & \\
\hline
\end{tabular}

Sumber : Olah Data Hasil Kuesioner, 2018

\section{Garis Kontinum Penilaian}

Tentang Hotel syariah menyediakan berbagai tipe kamar yang sesuai dengan kebutuhan

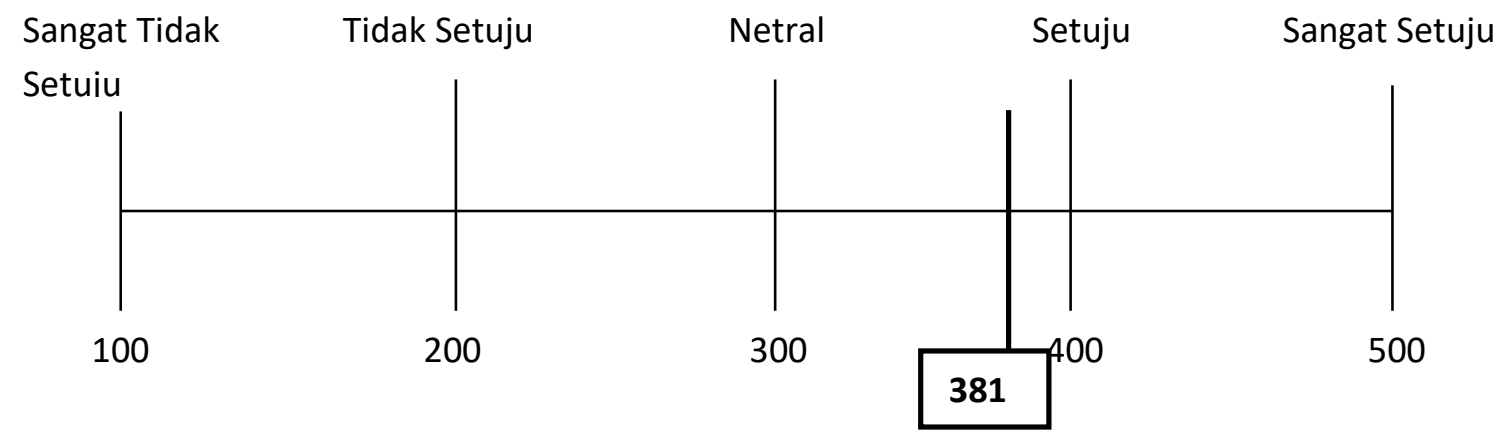

Sumber : Olah Data Hasil Kuesioner, 2018

Berdasarkan gambar garis kontinum diatas dari hasil hitungan 1 (satu) dimensi di atas mengenai tipe kamar yang sesuai dengan kebutuhan mencapai nilai 381 yang termasuk dalam kategori setuju. 
b. Penilaian Terhadap Hotel syariah menyediakan ruang pertemuan dan menyediakan berbagai makanan yang halal.
Berdasarkan data yang didapat melalui penyebaran kuesioner terhadap para pengunjung di Sofyan Inn Srigunting Bogor dengan jumlah 100 orang mengenai penilaian Tentang Hotel syariah menyediakan ruang pertemuan dan menyediakan berbagai makanan yang halal.

\section{Penilaian Responden}

Tentang Hotel syariah menyediakan ruang pertemuan dan menyediakan berbagai makanan yang halal.

\begin{tabular}{|c|c|c|c|c|c|c|}
\hline \multirow[b]{2}{*}{ Responden } & \multicolumn{5}{|c|}{ Sikap } & \multirow[b]{2}{*}{ Skor } \\
\hline & $\begin{array}{c}\text { Sangat tidak } \\
\text { setuju }\end{array}$ & $\begin{array}{l}\text { Tidak } \\
\text { Setuju }\end{array}$ & Netral & Setuju & $\begin{array}{l}\text { Sangat } \\
\text { Setuju }\end{array}$ & \\
\hline 8 & & & & & $\checkmark$ & $8 \times 5=40$ \\
\hline 71 & & & & $\checkmark$ & & $71 \times 4=284$ \\
\hline 17 & & & $\checkmark$ & & & $17 \times 3=51$ \\
\hline 4 & & $\checkmark$ & & & & $4 \times 2=8$ \\
\hline 0 & & & & & & 0 \\
\hline \multicolumn{6}{|c|}{ Total } & 383 \\
\hline Persentase & $0 \%$ & $4 \%$ & $17 \%$ & $71 \%$ & $8 \%$ & \\
\hline
\end{tabular}

Sumber : Olah Data Hasil Kuesioner, 2018

\section{Garis Kontinum Penilaian}

Tentang Hotel syariah menyediakan ruang pertemuan dan menyediakan berbagai makanan yang halal.

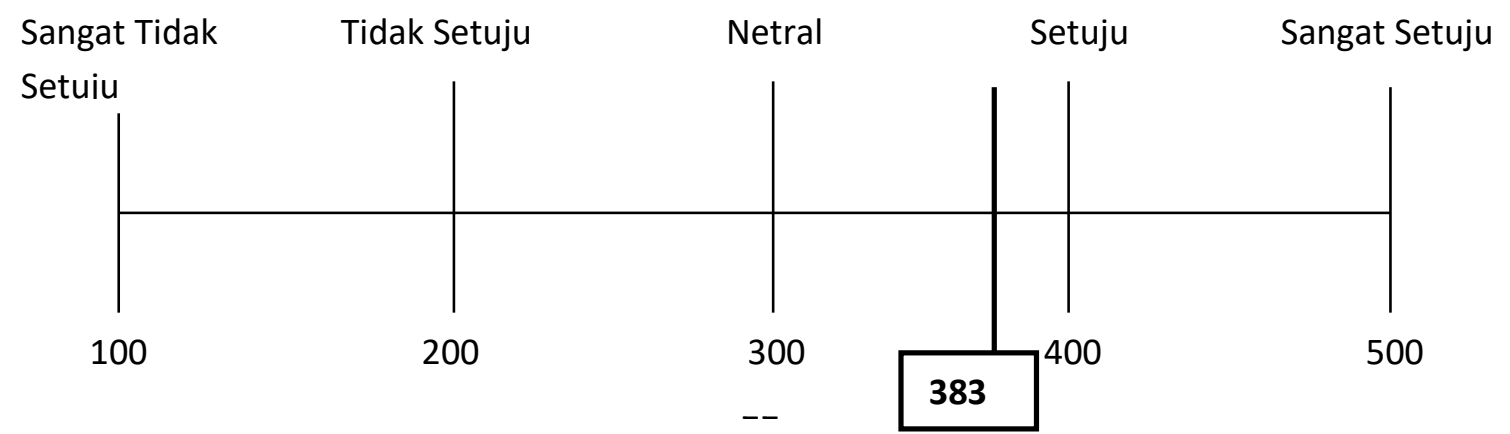


Berdasarkan gambar garis kontinum diatas dari hasil hitungan 1 (satu) dimensi di atas mengenai hotel syariah Sofyan Inn Srigunting Bogor menyediakan ruang pertemuan dan menyediakan berbagai makanan yang halal mencapai nilai 383 yang termasuk dalam kategori setuju.

\section{Kuesioner Penilaian Harga Jasa Penginapan}

Berbasis Syariah Di Hotel

Sofyan Inn a. Penilaian Responden Harga Jasa Penginapan Berbasis Syariah Di Hotel Sofyan Inn Srigunting Bogor

Berdasarkan data yang didapat melalui penyebaran kuesioner terhadap para pengunjung di Hotel Sofyan Inn Srigunting Bogor dengan jumlah 100 orang mengenai penilaian Tentang Harga Jasa Penginapan Berbasis Syariah di Hotel Sofyan Inn Srigunting Bogor.

\section{Srigunting Bogor}

\section{Penilaian Responden}

Tentang Harga hotel syariah sesuai dengan pelayanan dan fasilitas yang di dapatkan

\begin{tabular}{|c|c|c|c|c|c|c|}
\hline \multirow[b]{2}{*}{ Responden } & \multicolumn{5}{|c|}{ Sikap } & \multirow[b]{2}{*}{ Skor } \\
\hline & $\begin{array}{c}\text { Sangat tidak } \\
\text { setuju }\end{array}$ & $\begin{array}{l}\text { Tidak } \\
\text { Setuju }\end{array}$ & Netral & Setuju & $\begin{array}{l}\text { Sangat } \\
\text { Setuju }\end{array}$ & \\
\hline 11 & & & & & $\checkmark$ & $11 \times 5=55$ \\
\hline 74 & & & & $\checkmark$ & & $74 \times 4=296$ \\
\hline 14 & & & $\checkmark$ & & & $14 \times 3=42$ \\
\hline 1 & & $\checkmark$ & & & & $1 \times 2=2$ \\
\hline 0 & & & & & & 0 \\
\hline \multicolumn{6}{|c|}{ Total } & 395 \\
\hline Persentase & $0 \%$ & $1 \%$ & $14 \%$ & $74 \%$ & $11 \%$ & \\
\hline
\end{tabular}

Sumber : Olah Data Hasil Kuesioner, 2018

\section{Garis Kontinum Penilaian}

Tentang Harga hotel syariah sesuai dengan pelayanan dan fasilitas yang di dapatkan

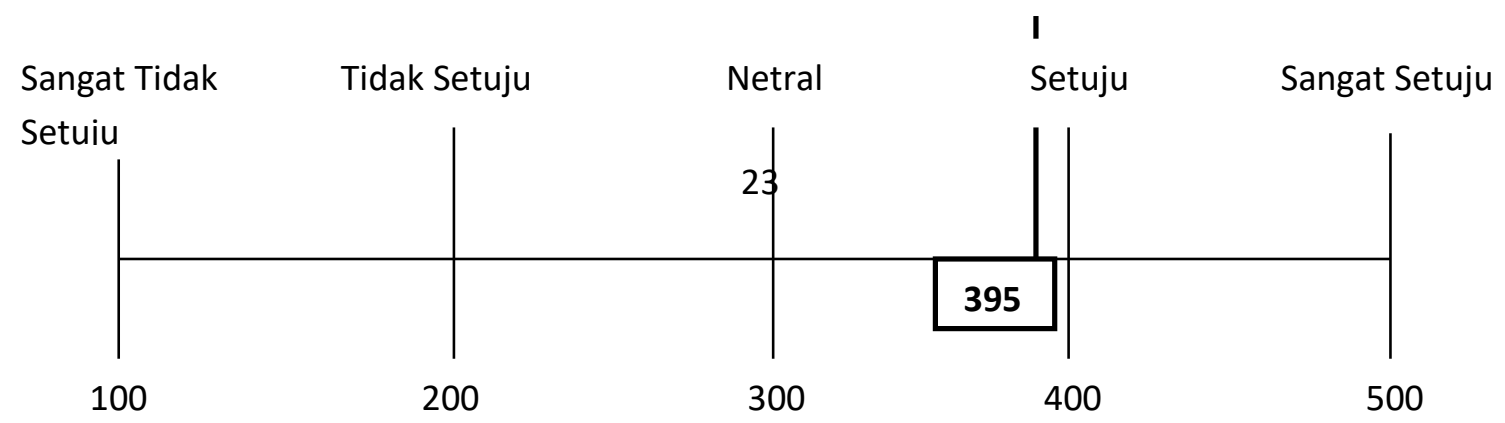


Berdasarkan gambar garis kontinum diatas dari hasil hitungan 1 (satu) dimensi di atas bahwa harga hotel syariah Sofyan Inn Srigunting Bogor sesuai dengan pelayanan dan fasilitas yang di dapatkan mencapai nilai 395 yang termasuk dalam kategori Setuju.

\section{b. Penilaian Responden Tentang Harga hotel} syariah dapat bersaing dengan hotel konvensional.
Berdasarkan data yang didapat melalui penyebaran kuesioner terhadap para pengunjung di Hotel Sofyan Inn Srigunting Bogor dengan jumlah 100 orang mengenai penilaian tentang harga hotel syariah dapat bersaing dengan hotel konvensional.

\section{Penilaian Responden}

Tentang Harga hotel syariah dapat bersaing dengan hotel konvensional.

\begin{tabular}{|c|c|c|c|c|c|c|}
\hline \multirow[b]{2}{*}{ Responden } & \multicolumn{5}{|c|}{ Sikap } & \multirow[b]{2}{*}{ Skor } \\
\hline & $\begin{array}{c}\text { Sangat tidak } \\
\text { setuju }\end{array}$ & $\begin{array}{l}\text { Tidak } \\
\text { Setuju }\end{array}$ & Netral & Setuju & $\begin{array}{l}\text { Sangat } \\
\text { Setuju }\end{array}$ & \\
\hline 10 & & & & & $\checkmark$ & $10 \times 5=50$ \\
\hline 69 & & & & $\checkmark$ & & $69 \times 4=276$ \\
\hline 18 & & & $\checkmark$ & & & $18 \times 3=54$ \\
\hline 3 & & $\checkmark$ & & & & $3 \times 2=6$ \\
\hline $\mathbf{0}$ & & & & & & $\mathbf{0}$ \\
\hline \multicolumn{6}{|c|}{ Total } & 386 \\
\hline Persentase & $0 \%$ & $3 \%$ & $18 \%$ & $69 \%$ & $10 \%$ & \\
\hline
\end{tabular}

Sumber : Olah Data Hasil Kuesioner, 2018

\section{Garis Kontinum Penilaian}

Tentang Harga hotel syariah dapat bersaing dengan hotel konvensional.

Sangat Tidak

Setuiu
Tidak Setuju

Netral

\begin{tabular}{|l|l|l|l|l|} 
& & & \\
\hline & & & &
\end{tabular}

Setuju

Sangat Setuju 
Berdasarkan gambar garis kontinum diatas dari hasil hitungan 1 (satu) dimensi di atas bahwa Tentang Harga hotel syariah dapat bersaing dengan hotel konvensional mencapai nilai 386 yang termasuk dalam kategori setuju.

Kuesioner Penilaian Tentang Hotel Syariah Terletak di Tempat Strategis di Kota Bogor a. Penilaian Terhadap Tentang Hotel syariah terletak di tempat yang strategis di kota Bogor

Berdasarkan data yang didapat melalui penyebaran kuesioner terhadap para pengunjung di hotel Sofyan Inn Srigunting Bogor dengan jumlah 100 orang mengenai penilaian tentang hotel syariah terletak di tempat yang strategis di kota Bogor.

\section{Penilaian Responden}

Tentang Hotel syariah terletak di tempat yang strategis di kota Bogor

\begin{tabular}{c|c|c|c|r|c|c}
\hline \multirow{2}{*}{ Responden } & \multicolumn{5}{c|}{ Sikap } & \multirow{2}{*}{ Skor } \\
\cline { 2 - 7 } & $\begin{array}{c}\text { Sangat tidak } \\
\text { setuju }\end{array}$ & $\begin{array}{c}\text { Tidak } \\
\text { Setuju }\end{array}$ & Netral & Setuju & $\begin{array}{c}\text { Sangat } \\
\text { Setuju }\end{array}$ & \\
\hline 16 & & & & & $\checkmark$ & $16 \times 5=80$ \\
\hline 66 & & & & $\checkmark$ & & $65 \times 4=260$ \\
\hline 19 & & & & & & $19 \times 3=57$ \\
\hline 0 & & & & & & 0 \\
\hline 0 & $\mathbf{0}$ & & & & \\
\hline Persentase & $\mathbf{0 \%}$ & $\mathbf{0 \%}$ & $\mathbf{1 9 \%}$ & $\mathbf{6 5 \%}$ & $\mathbf{1 6 \%}$ & \\
\hline
\end{tabular}

Sumber : Olah Data Hasil Kuesioner, 2018

\section{Garis Kontinum Penilaian}

Tentang Hotel syariah terletak di tempat yang strategis di kota Bogor 


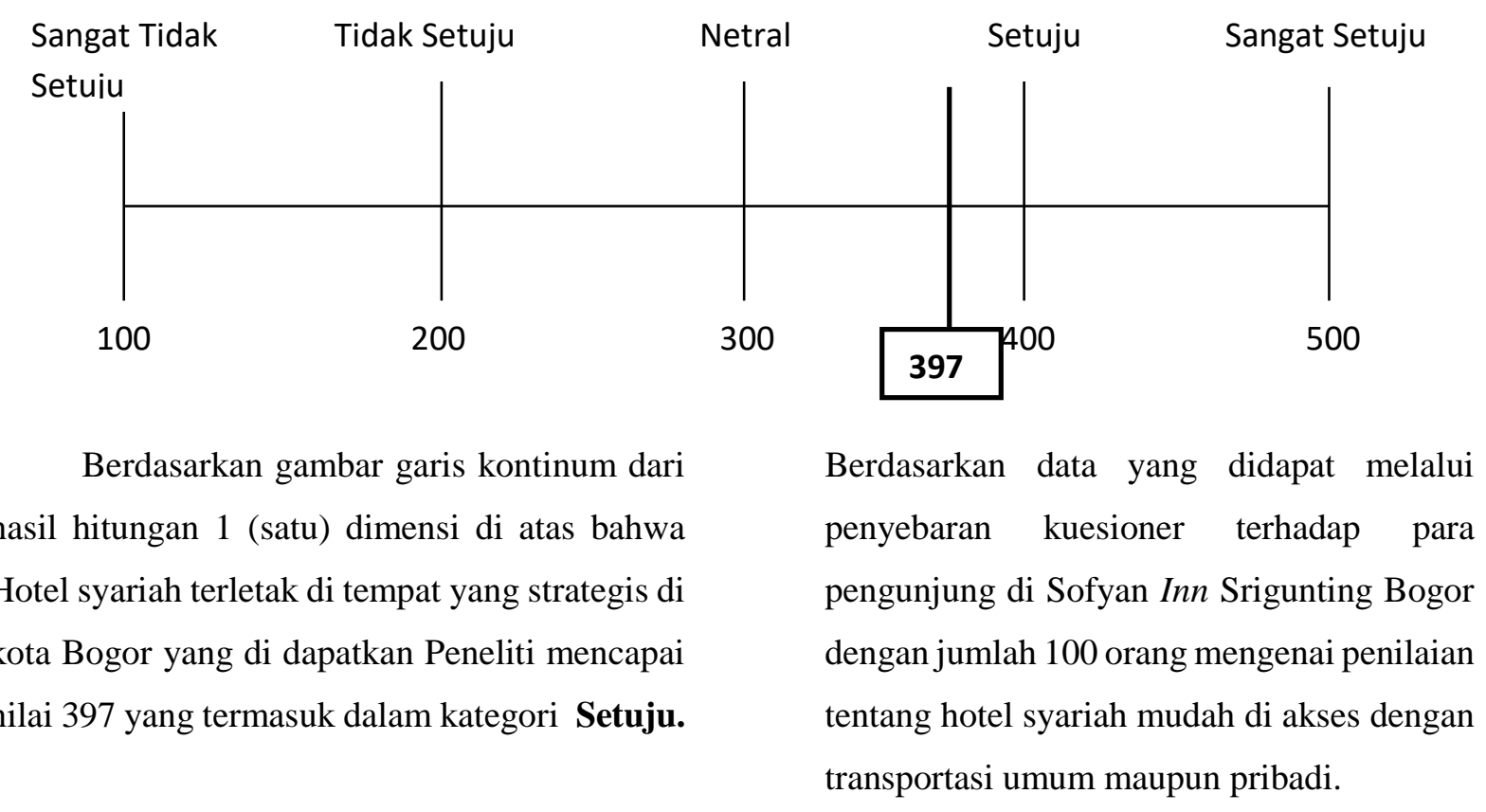

b. Penilaian Terhadap Tentang Hotel syariah mudah di akses dengan transportasi umum maupun pribadi

\section{Penilaian Responden}

Tentang Hotel syariah mudah di akses dengan transportasi umum maupun pribadi

\begin{tabular}{c|c|c|c|r|c|c}
\hline \multirow{2}{*}{ Responden } & \multicolumn{5}{c|}{ Sikap } & \multirow{2}{*}{ Skor } \\
\cline { 2 - 7 } & $\begin{array}{c}\text { Sangat tidak } \\
\text { setuju }\end{array}$ & $\begin{array}{c}\text { Tidak } \\
\text { Setuju }\end{array}$ & Netral & Setuju & $\begin{array}{c}\text { Sangat } \\
\text { Setuju }\end{array}$ & \\
\hline 15 & & & & & $\checkmark$ & $15 \times 5=75$ \\
\hline 70 & & & & $\checkmark$ & & $70 \times 4=280$ \\
\hline 15 & & & $\checkmark$ & & & $15 \times 3=45$ \\
\hline 0 & & & & & & 0 \\
\hline 0 & $\mathbf{0 \%}$ & $\mathbf{0 \%}$ & $\mathbf{1 5 \%}$ & $\mathbf{7 0 \%}$ & $\mathbf{1 5 \%}$ & \\
\hline Persentase & $\mathbf{0 \%}$ & & & \\
\hline
\end{tabular}

Sumber : Olah Data Hasil Kuesioner, 2018

\section{Garis Kontinum Penilaian}

Tentang Hotel syariah mudah di akses dengan transportasi umum maupun pribadi

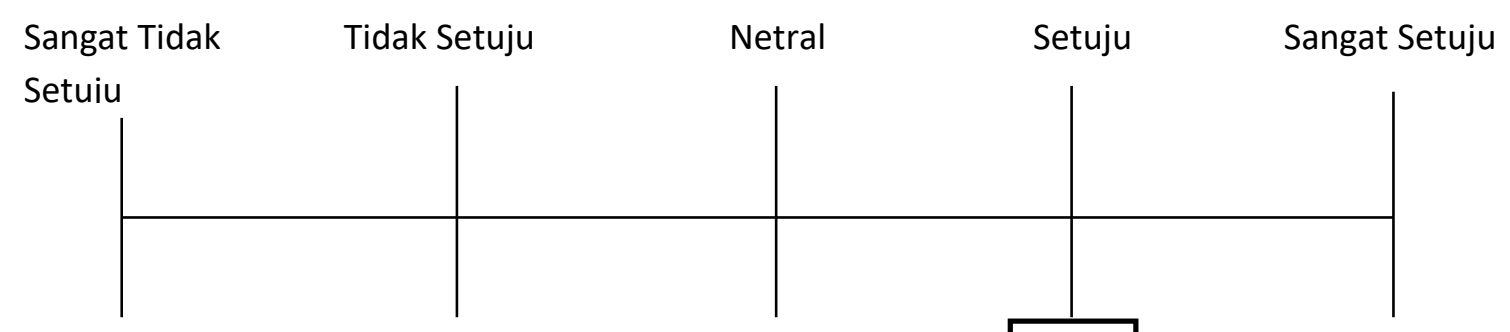


Sumber : Olah Data Hasil Kuesioner, 2018

Berdasarkan gambar garis kontinum diatas dari hasil hitungan 1 (satu) dimensi di atas bahwa tentang hotel syariah Sofyan Inn Srigunting Bogor mudah di akses dengan transportasi umum maupun pribadi mencapai nilai 400 yang termasuk dalam kategori Setuju.

\section{Kuesioner Penilaian Tentang Hotel syariah} sangat mudah di temukan di internet dan website. a. Penilaian Terhadap Tentang Hotel syariah sangat mudah di temukan di internet dan website.

Berdasarkan data yang didapat melalui penyebaran kuesioner terhadap para pengunjung di Sofyan Inn Srigunting Bogor dengan jumlah 100 orang mengenai penilaian tentang hotel syariah sangat mudah di temukan di internet dan website.

\section{Penilaian Responden}

Tentang Hotel syariah sangat mudah di temukan di internet dan website.

\begin{tabular}{|c|c|c|c|c|c|c|}
\hline \multirow[b]{2}{*}{ Responden } & \multicolumn{5}{|c|}{ Sikap } & \multirow[b]{2}{*}{ Skor } \\
\hline & $\begin{array}{c}\text { Sangat tidak } \\
\text { setuju }\end{array}$ & $\begin{array}{l}\text { Tidak } \\
\text { Setuju }\end{array}$ & Netral & Setuju & $\begin{array}{l}\text { Sangat } \\
\text { Setuju }\end{array}$ & \\
\hline 19 & & & & & $\checkmark$ & $19 \times 5=95$ \\
\hline 67 & & & & $\checkmark$ & & $67 \times 4=268$ \\
\hline 14 & & & $\checkmark$ & & & $14 \times 3=42$ \\
\hline 0 & & & & & & 0 \\
\hline 0 & & & & & & 0 \\
\hline \multicolumn{6}{|c|}{ Total } & 405 \\
\hline Persentase & $0 \%$ & $0 \%$ & $14 \%$ & $66 \%$ & $19 \%$ & \\
\hline
\end{tabular}

Sumber : Olah Data Hasil Kuesioner, 2018 


\section{Garis Kontinum Penilaian}

Tentang Hotel syariah sangat mudah di temukan di internet dan website.

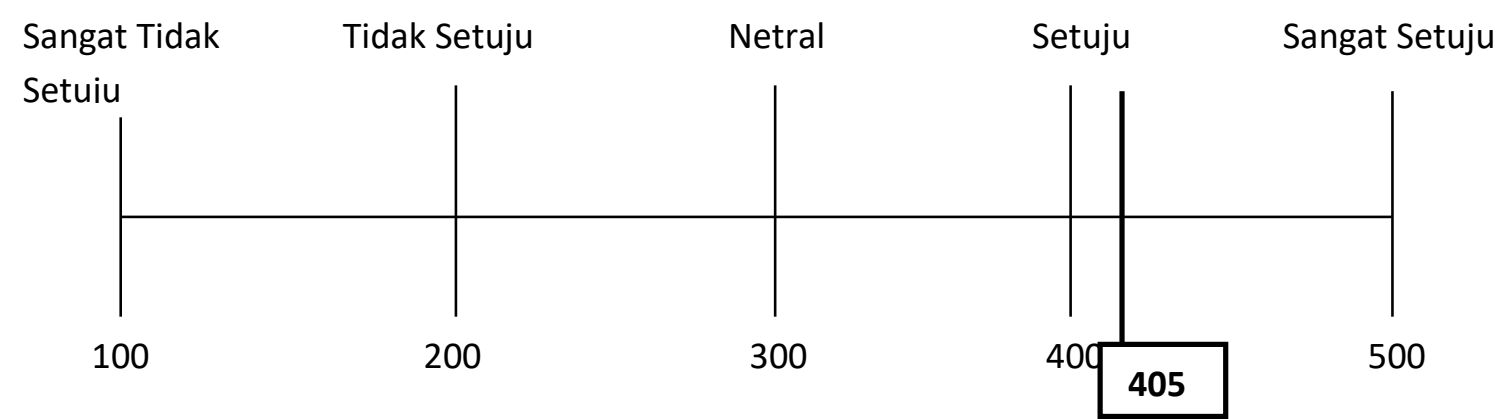

Sumber : Olah Data Hasil Kuesioner, 2018

Berdasarkan gambar garis kontinum dari hasil hitungan 1 (satu) dimensi di atas bahwa hotel syariah Sofyan Inn Srigunting Bogor sangat mudah di temukan di internet dan website mencapai nilai 405 yang termasuk dalam kategori Setuju.

b. Penilaian Tentang Hotel syariah promosikan produknya di kemas dengan menarik dan mudah di pahami

\section{Penilaian Responden}

Tentang Hotel syariah promosikan produknya di kemas dengan menarik dan mudah di pahami

\begin{tabular}{c|c|c|c|c|c|c}
\hline \multirow{2}{*}{ Responden } & \multicolumn{5}{|c|}{ Sikap } & \multirow{2}{*}{ Skor } \\
\cline { 2 - 7 } & $\begin{array}{c}\text { Sangat tidak } \\
\text { setuju }\end{array}$ & $\begin{array}{c}\text { Tidak } \\
\text { Setuju }\end{array}$ & Netral & Setuju & $\begin{array}{c}\text { Sangat } \\
\text { Setuju }\end{array}$ & \\
\hline 22 & & & & & $\checkmark$ & $22 \times 5=110$ \\
\hline 63 & & & & $\checkmark$ & & $63 \times 4=252$ \\
\hline 15 & & & $\checkmark$ & & & $15 \times 3=45$ \\
\hline
\end{tabular}




\begin{tabular}{c|c|c|c|c|c|c}
\cline { 5 - 6 } 0 & & & & & 0 \\
\hline 0 & & & & & & 0 \\
\hline \multicolumn{7}{c}{ Total } \\
\hline Persentase & $\mathbf{0 \%}$ & $\mathbf{0 \%}$ & $\mathbf{1 5 \%}$ & $\mathbf{6 3 \%}$ & $\mathbf{2 2 \%}$ & $\mathbf{4 0 7}$ \\
\hline
\end{tabular}

Sumber : Olah Data Hasil Kuesioner, 2018

\section{Garis Kontinum Penilaian}

Tentang Hotel syariah promosikan produknya di kemas dengan menarik dan mudah di pahami

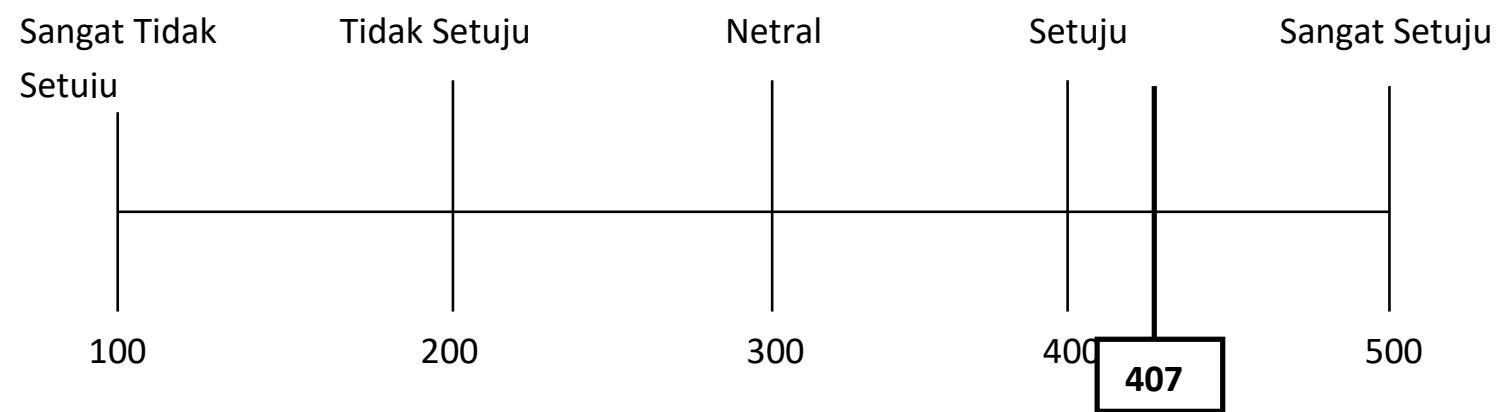

Berdasarkan gambar garis kontinum dari hasil hitungan 1 (satu) dimensi di atas bahwa hotel syariah Sofyan Inn Srigunting Bogor promosikan produknya di kemas dengan menarik dan mudah di pahami mencapai nilai 407 yang termasuk dalam kategori Setuju.

Kuesioner Penilaian Tentang Karyawan Hotel Syariah Selalu Mengucapkan Assalamualaikum Ketika Menerima Tamu. a. Penilaian Responden Tentang Karyawan hotel syariah selalu mengucapkan Assalamualaikum ketika menerima tamu.

Berdasarkan data yang didapat melalui penyebaran kuesioner terhadap para pengunjung di Sofyan Inn Srigunting Bogor dengan jumlah 100 orang mengenai penilaian tentang karyawan hotel syariah selalu mengucapkan Assalamualaikum ketika menerima tamu.

\section{Penilaian Responden.}

Tentang Karyawan hotel syariah selalu mengucapkan

Assalamualaikum ketika menerima tamu.

\begin{tabular}{|c|c|c|c|c|c|c|}
\hline \multirow[b]{2}{*}{ Responden } & \multicolumn{5}{|c|}{ Sikap } & \multirow[b]{2}{*}{ Skor } \\
\hline & $\begin{array}{c}\text { Sangat tidak } \\
\text { setuju }\end{array}$ & $\begin{array}{l}\text { Tidak } \\
\text { Setuju }\end{array}$ & Netral & Setuju & $\begin{array}{l}\text { Sangat } \\
\text { Setuju }\end{array}$ & \\
\hline
\end{tabular}




\begin{tabular}{|c|c|c|c|c|c|c|}
\hline 27 & & & & & $\checkmark$ & $27 \times 5=135$ \\
\hline 59 & & & & $\checkmark$ & & $59 \times 4=236$ \\
\hline 14 & & & $\checkmark$ & & & $14 \times 3=42$ \\
\hline 0 & & & & & & 0 \\
\hline 0 & & & & & & 0 \\
\hline \multicolumn{6}{|c|}{ Total } & 413 \\
\hline Persentase & $0 \%$ & $0 \%$ & $14 \%$ & $59 \%$ & $27 \%$ & \\
\hline
\end{tabular}

Sumber : Olah Data Hasil Kuesioner, 2018

\section{Garis Kontinum Penilaian}

Tentang Karyawan hotel syariah selalu mengucapkan Assalamualaikum ketika menerima tamu.

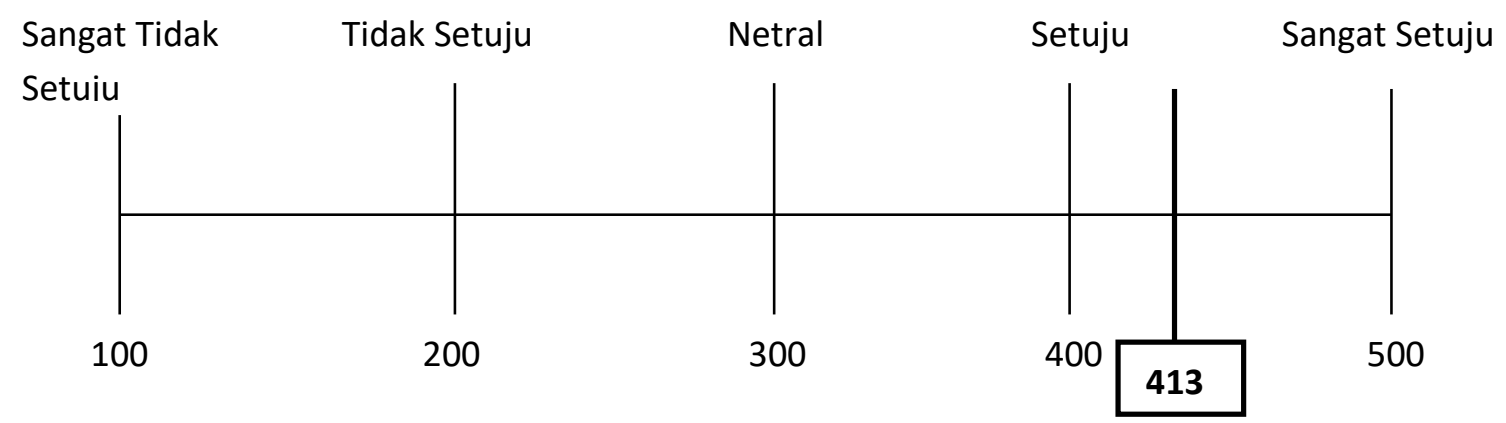

Berdasarkan gambar garis kontinum 9 dari hasil hitungan 1 (satu) dimensi di atas bahwa Karyawan hotel syariah Sofyan Inn Srigunting Bogor selalu mengucapkan Assalamualaikum ketika menerima tamu.yang mencapai nilai 413 yang termasuk dalam kategori Setuju. b. Penilaian Tentang Karyawan hotel syariah berpenampilan sopan

Berdasarkan data yang didapat melalui penyebaran kuesioner terhadap para pengunjung di Sofyan Inn Srigunting Bogor dengan jumlah 100 orang mengenai penilaian Tentang Karyawan hotel syariah berpenampilan sopan.

\section{Penilaian Responden}

Tentang Karyawan hotel syariah berpenampilan sopan

\begin{tabular}{|c|c|c|c|c|c|c|}
\hline \multirow[b]{2}{*}{ Responden } & \multicolumn{5}{|c|}{ Sikap } & \multirow[b]{2}{*}{ Skor } \\
\hline & $\begin{array}{c}\text { Sangat tidak } \\
\text { setuju }\end{array}$ & $\begin{array}{l}\text { Tidak } \\
\text { Setuju }\end{array}$ & Netral & Setuju & $\begin{array}{l}\text { Sangat } \\
\text { Setuju }\end{array}$ & \\
\hline
\end{tabular}




\begin{tabular}{|c|c|c|c|c|c|c|}
\hline 23 & & & & & $\checkmark$ & $23 \times 5=115$ \\
\hline 67 & & & & $\checkmark$ & & $67 \times 4=268$ \\
\hline 7 & & & $\checkmark$ & & & $7 \times 3=21$ \\
\hline 3 & & $\checkmark$ & & & & $3 \times 2=6$ \\
\hline 0 & & & & & & 0 \\
\hline \multicolumn{6}{|c|}{ Total } & 410 \\
\hline Persentase & $0 \%$ & $3 \%$ & $7 \%$ & $67 \%$ & $23 \%$ & \\
\hline
\end{tabular}

Sumber : Olah Data Hasil Kuesioner, 2018

\section{Garis Kontinum Penilaian}

Tentang Karyawan hotel syariah berpenampilan sopan

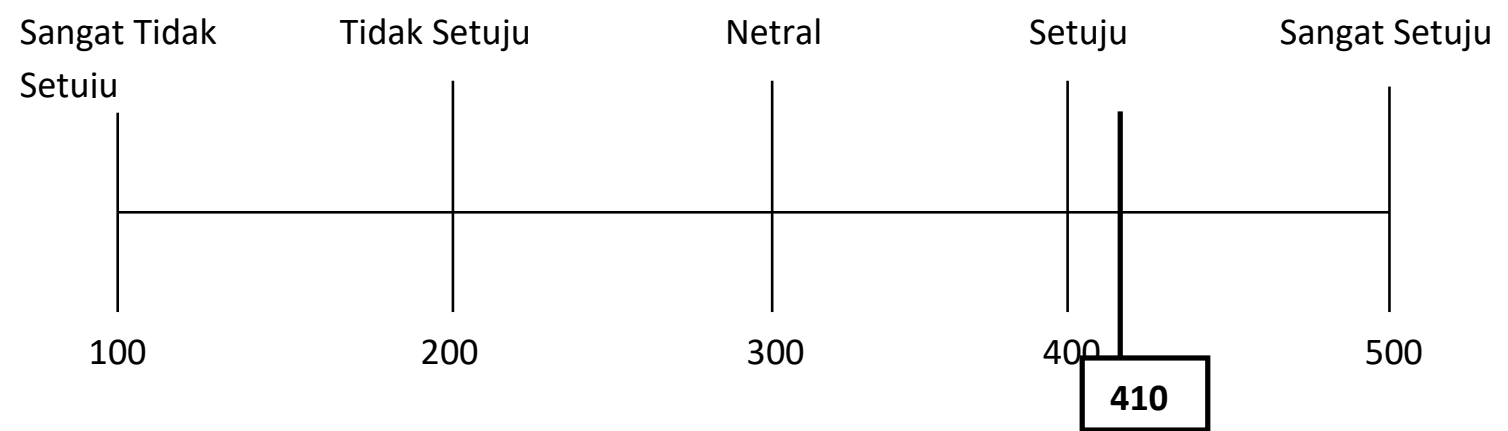

Sumber : Olah Data Hasil Kuesioner, 2018

Berdasarkan gambar garis kontinum dari hasil hitungan 1 (satu) dimensi di atas bahwa karyawan hotel syariah Sofyan Inn Srigunting Bogor berpenampilan sopan yang mencapai nilai 410 yang termasuk dalam kategori Setuju.

\section{Kuesioner Penilaian Tentang Proses Pemesanan (booking) Hotel Syariah Sangat Mudah dan Cepat.}

a. Penilaian responden Tentang Proses Pemesanan (booking) hotel syariah sangat mudah dan cepat.

Berdasarkan data yang didapat melalui penyebaran kuesioner terhadap para pengunjung di Sofyan Inn Srigunting Bogor dengan jumlah 100 orang mengenai penilaian Tentang Proses Pemesanan (booking) hotel syariah sangat mudah dan cepat.

\section{Penilaian Responden}

Tentang Proses Pemesanan (booking) hotel syariah sangat mudah dan cepat. 


\begin{tabular}{|c|c|c|c|r|c|c}
\hline \multirow{2}{*}{ Responden } & \multicolumn{5}{|c|}{ Sikap } & \multirow{2}{*}{ Skor } \\
\cline { 2 - 6 } & $\begin{array}{c}\text { Sangat tidak } \\
\text { setuju }\end{array}$ & $\begin{array}{c}\text { Tidak } \\
\text { Setuju }\end{array}$ & Netral & Setuju & $\begin{array}{c}\text { Sangat } \\
\text { Setuju }\end{array}$ & \\
\hline 22 & & & & & $\checkmark$ & $22 \times 5=110$ \\
\hline 67 & & & & $\checkmark$ & & $67 \times 4=268$ \\
\hline 11 & & & $\checkmark$ & & & $11 \times 3=33$ \\
\hline 0 & & & & & & 0 \\
\hline 0 & & & & & & 0 \\
\hline Persentase & $\mathbf{0 \%}$ & $\mathbf{3 \%}$ & $\mathbf{7 \%}$ & $\mathbf{6 7 \%}$ & $\mathbf{2 3 \%}$ & \\
\hline
\end{tabular}

Sumber : Olah Data Hasil Kuesioner, 2018

\section{Garis Kontinum Penilaian}

Tentang Proses Pemesanan (booking) hotel syariah sangat mudah dan cepat.

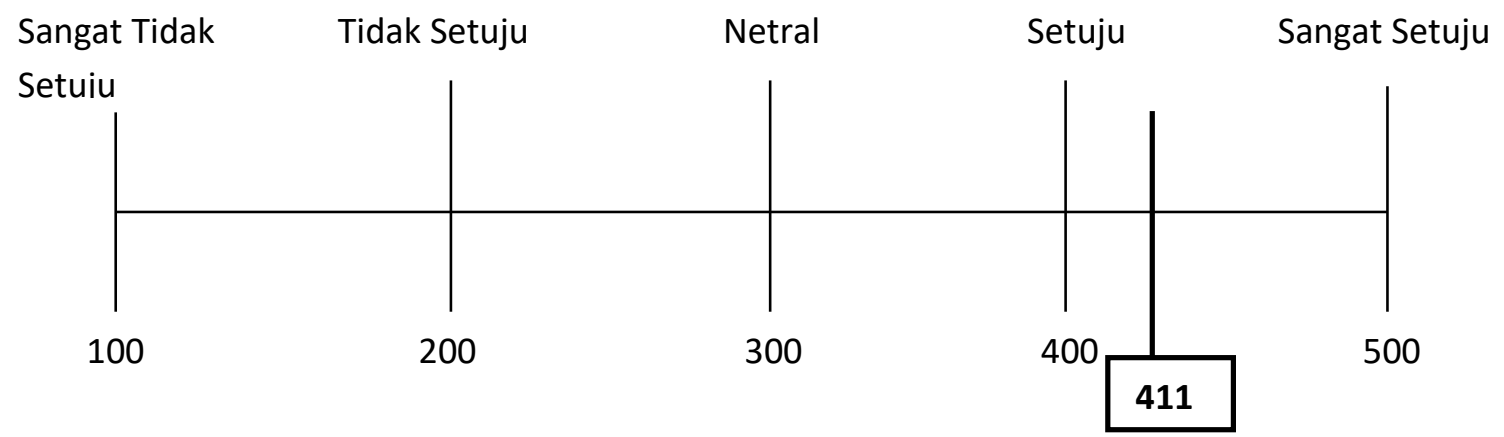

Sumber : Olah Data Hasil Kuesioner 2018

Berdasarkan gambar garis kontinum dari hasil hitungan 1 (satu) dimensi di atas bahwa Proses Pemesanan (booking) hotel syariah Sofyan Inn Srigunting Bogor sangat mudah dan cepat yang di dapatkan Peneliti mencapai nilai 411 yang termasuk dalam kategori Setuju.

\section{b. Penilaian responden Tentang Proses} pembersihan dan persiapan kamar hotel syariah sangat cekatan,cepat,dan bersih (clean).

Berdasarkan data yang didapat melalui penyebaran kuesioner terhadap para pengunjung di Sofyan Inn Srigunting Bogor dengan jumlah 100 orang mengenai penilaian Tentang Proses pembersihan dan persiapan kamar hotel syariah sangat cekatan,cepat,dan bersih (clean).

\section{Penilaian Responden}

Tentang Proses pembersihan dan persiapan kamar hotel syariah 


\begin{tabular}{c|c|c|r|r|r|c}
\multicolumn{7}{c}{ Sangat cekatan,cepat,dan bersih (clean). } \\
\hline \multirow{2}{*}{ Responden } & \multicolumn{5}{c}{ Sikap } & \multirow{2}{*}{ Skor } \\
\cline { 2 - 7 } & $\begin{array}{c}\text { Sangat tidak } \\
\text { setuju }\end{array}$ & $\begin{array}{c}\text { Tidak } \\
\text { Setuju }\end{array}$ & Netral & Setuju & $\begin{array}{c}\text { Sangat } \\
\text { Setuju }\end{array}$ & \\
\hline 26 & & & & & $\checkmark$ & $26 \times 5=130$ \\
\hline 64 & & & & $\checkmark$ & & $64 \times 4=256$ \\
\hline 10 & & & $\checkmark$ & & & $10 \times 3=30$ \\
\hline 0 & & & & & & 0 \\
\hline 0 & & & & & & 0 \\
\hline Persentase & $\mathbf{0 \%}$ & $\mathbf{0 \%}$ & $\mathbf{1 0 \%}$ & $\mathbf{6 4 \%}$ & $\mathbf{2 6 \%}$ & \\
\hline
\end{tabular}

Sumber : Olah Data Hasil Kuesioner, 2018

\section{Garis Kontinum Penilaian}

Tentang Proses pembersihan dan persiapan kamar hotel syariah sangat cekatan,cepat,dan bersih (clean).

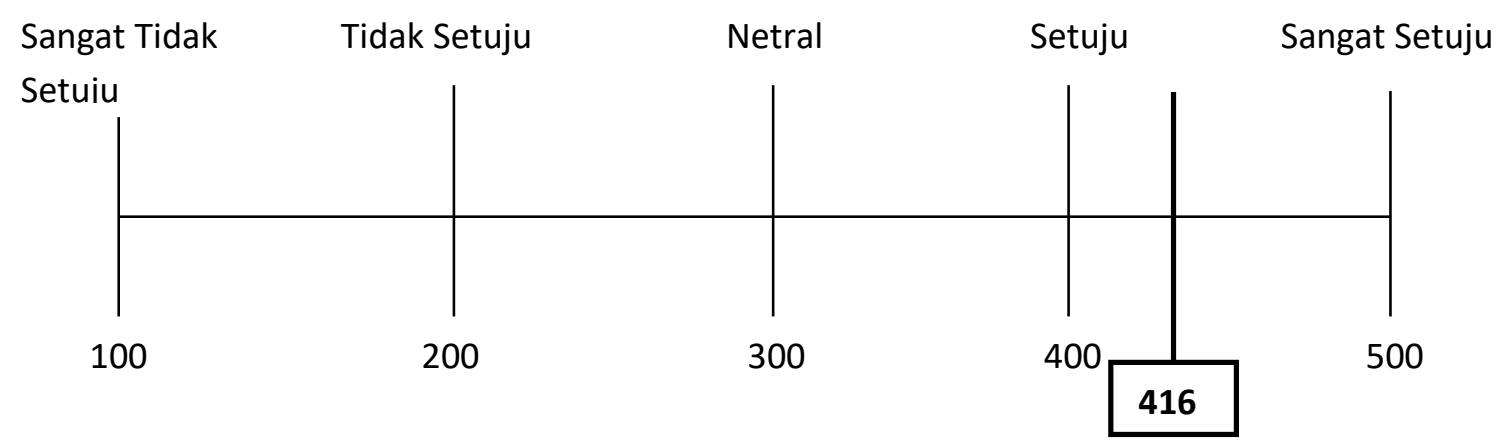

Berdasarkan gambar garis kontinum dari hasil hitungan 1 (satu) dimensi di atas bahwa Proses pembersihan dan persiapan kamar hotel syariah Sofyan Inn Srigunting Bogor sangat cekatan, cepat, dan bersih (clean) yang mencapai nilai 416 yang termasuk dalam kategori Setuju.

Kuesioner Penilaian Tentang Hotel Syariah Tata Bangunannya Bernuansa Islami a. Penilaian responden Tentang Hotel syariah tata bangunan nya bernuansa islami

Berdasarkan data yang didapat melalui penyebaran kuesioner terhadap para pengunjung di Sofyan Inn Srigunting Bogor dengan jumlah 100 orang mengenai penilaian tentang hotel syariah tata bangunan nya bernuansa islami. 


\section{Penilaian Responden}

Tentang Hotel syariah tata bangunan nya bernuansa islami

\begin{tabular}{|c|c|c|c|c|c|c|}
\hline \multirow[b]{2}{*}{ Responden } & \multicolumn{5}{|c|}{ Sikap } & \multirow[b]{2}{*}{ Skor } \\
\hline & $\begin{array}{c}\text { Sangat tidak } \\
\text { setuju }\end{array}$ & $\begin{array}{l}\text { Tidak } \\
\text { Setuju }\end{array}$ & Netral & Setuju & $\begin{array}{l}\text { Sangat } \\
\text { Setuju }\end{array}$ & \\
\hline 14 & & & & & $\checkmark$ & $14 \times 5=70$ \\
\hline 75 & & & & $\checkmark$ & & $75 \times 4=300$ \\
\hline 11 & & & $\checkmark$ & & & $11 \times 3=33$ \\
\hline 0 & & & & & & 0 \\
\hline 0 & & & & & & 0 \\
\hline \multicolumn{6}{|c|}{ Total } & 403 \\
\hline Persentase & $0 \%$ & $0 \%$ & $11 \%$ & $75 \%$ & $14 \%$ & \\
\hline
\end{tabular}

Sumber : Olah Data Hasil Kuesioner, 2018

\section{Garis Kontinum Penilaian}

Tentang Hotel syariah tata bangunan nya bernuansa islami

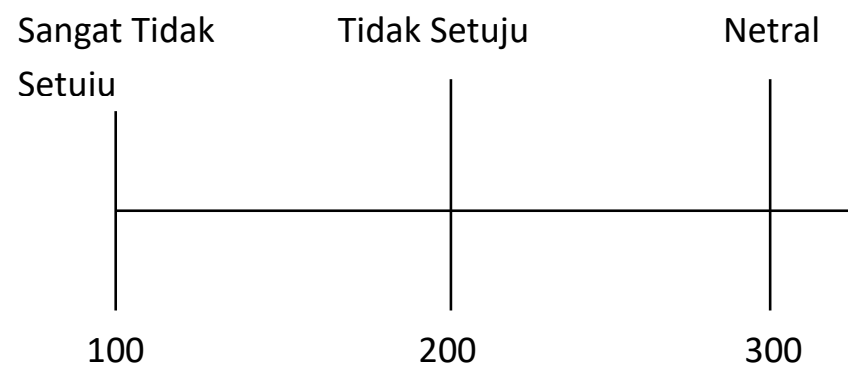

Setuju

Sangat Setuju

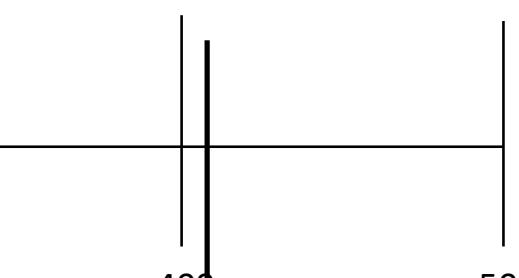

403

Berdasarkan gambar garis kontinum dari hasil hitungan 1 (satu) dimensi di atas bahwa hotel syariah Sofyan Inn Srigunting Bogor tata bangunan nya bernuansa islami mencapai nilai 403 yang termasuk dalam kategori Setuju.

\section{b. Penilaian responden Tentang Hotel syariah} menyediakan fasilitas lengkap, (Tv,minibar, Internet, water heater) dan perlengkapan ibadah (mukena dan alQur'an)

Berdasarkan data yang didapat melalui penyebaran kuesioner terhadap para pengunjung di Sofyan Inn Srigunting Bogor dengan jumlah 100 orang mengenai penilaian tentang hotel syariah menyediakan fasilitas lengkap, (Tv,minibar, Internet, water heater) dan perlengkapan ibadah (mukena dan alQur'an). 


\section{Penilaian Responden}

Tentang Hotel syariah menyediakan fasilitas lengkap, (Tv,minibar, Internet, water heater) dan perlengkapan ibadah (mukena dan al-Qur'an)

\begin{tabular}{c|c|c|c|c|c|c}
\hline \multirow{2}{*}{ Responden } & \multicolumn{5}{c|}{ Sikap } & \multirow{2}{*}{ Skor } \\
\cline { 2 - 7 } & $\begin{array}{c}\text { Sangat tidak } \\
\text { setuju }\end{array}$ & $\begin{array}{c}\text { Tidak } \\
\text { Setuju }\end{array}$ & Netral & Setuju & $\begin{array}{c}\text { Sangat } \\
\text { Setuju }\end{array}$ & \\
\hline 49 & & & & & $\checkmark$ & $49 \times 5=245$ \\
\hline 47 & & & & $\checkmark$ & & $47 \times 4=188$ \\
\hline 3 & & $\checkmark$ & & & & $3 \times 3=9$ \\
\hline 1 & & & & & & 0 \\
\hline 0 & \multicolumn{7}{|c|}{ Total } & & & & 4 \\
\hline Persentase & $\mathbf{0 \%}$ & $\mathbf{1 \%}$ & $\mathbf{3 \%}$ & $\mathbf{4 7 \%}$ & $\mathbf{4 9 \%}$ & \\
\hline
\end{tabular}

Sumber : Olah Data Hasil Kuesioner, 2018

\section{Garis Kontinum Penilaian}

Tentang Hotel syariah menyediakan fasilitas lengkap, (Tv,minibar, Internet, water heater) dan perlengkapan ibadah (mukena dan al-Qur'an)

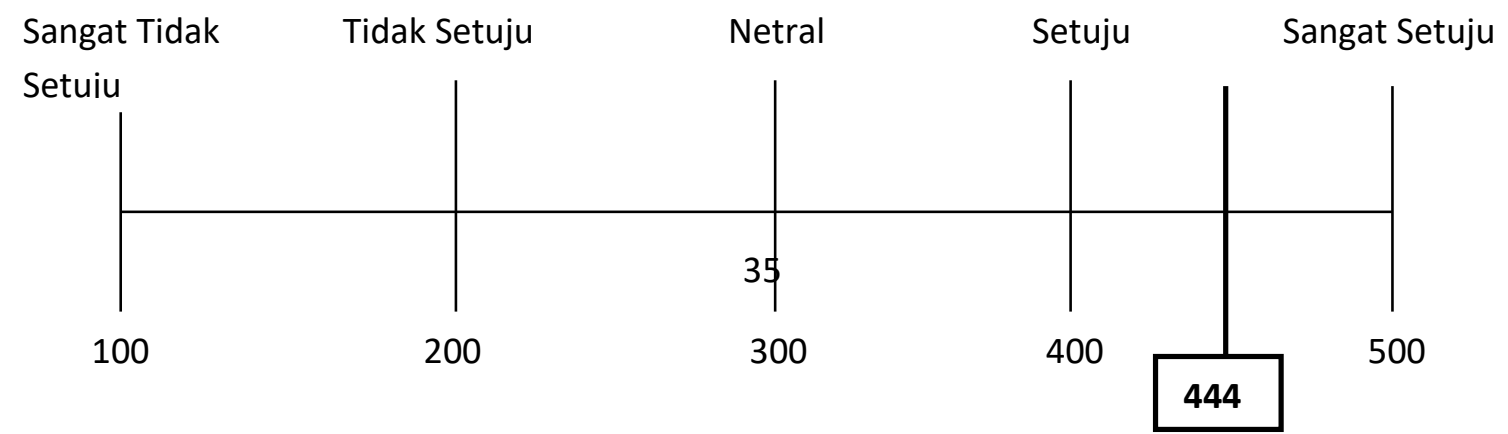


Sumber : Olah Data Hasil Kuesioner, 2018

Berdasarkan gambar garis kontinum dari hasil hitungan 1 (satu) dimensi di atas bahwa hotel syariah Sofyan Inn Srigunting Bogor menyediakan fasilitas lengkap, (Tv,minibar, Internet, water heater) dan perlengkapan ibadah (mukena dan al-Qur'an) mencapai nilai 444 yang termasuk dalam kategori Setuju.

Kesimpulan Penelitian Analisa Bauran

Pemasaran (Marketing mix) Jasa Penginapan

\begin{abstract}
Berbasis Syariah Di Hotel Sofyan Inn Srigunting Bogor

Berdasarkan data - data yang didapat dari penyebaran kuesioner yang dibagikan penulis kepada para pengunjung yang terlihat dalam penilaian terhadap Analisa Bauran Pemasaran (Marketing mix) Jasa Penginapan Berbasis Syariah Di Hotel di Sofyan Inn Bogor sebagai berikut :
\end{abstract}

Kesimpulan Penilaian Terhadap Analisa Bauran Pemasaran (Marketing mix) Jasa Penginapan Berbasis Syariah Di Hotel Sofyan Inn Srigunting Bogor

\begin{tabular}{l|c}
\hline \multicolumn{1}{c}{ Penilaian } & Skor \\
\hline Product & 381 \\
\hline $\begin{array}{l}\text { Hotel syariah menyediakan berbagai tipe kamar yang sesuai dengan } \\
\text { kebutuhan }\end{array}$ & \\
\hline $\begin{array}{l}\text { Hotel syariah menyediakan ruang pertemuan dan menyediakan berbagai } \\
\text { makanan yang halal }\end{array}$ & 383 \\
\hline Price & \\
\hline Harga hotel syariah sesuai dengan pelayanan dan fasilitas yang di dapatkan & 395 \\
\hline Harga hotel syariah dapat bersaing dengan hotel konvensional & 386 \\
\hline Place & 397 \\
\hline Hotel syariah terletak di tempat yang strategis di kota Bogor & 400 \\
\hline Hotel syariah mudah di akses dengan transportasi umum maupun pribadi & \\
\hline Promotion & \\
\hline
\end{tabular}




\begin{tabular}{l|c}
\hline Hotel syariah sangat mudah di temukan di internet dan website & 405 \\
\hline $\begin{array}{l}\text { Hotel syariah promosikan produknya di kemas dengan menarik dan mudah } \\
\text { di pahami }\end{array}$ & 407 \\
\hline People & 413 \\
\hline $\begin{array}{l}\text { Karyawan hotel syariah selalu mengucapkan Assalamualaikum ketika } \\
\text { menerima tamu. }\end{array}$ & 410 \\
\hline Karyawan hotel syariah berpenampilan sopan & 411 \\
\hline Process & 416 \\
\hline Proses Pemesanan (booking) hotel syariah sangat mudah dan cepat. \\
\hline $\begin{array}{l}\text { Proses pembersihan dan persiapan kamar hotel syariah sangat } \\
\text { cekatan,cepat,dan bersih (clean). }\end{array}$ \\
\hline Phsycal Evidence \\
\hline Hotel syariah tata bangunan nya bernuansa islami \\
\hline $\begin{array}{l}\text { Hotel syariah menyediakan fasilitas lengkap, (Tv,minibar, Internet, water } \\
\text { heater) dan perlengkapan ibadah (mukena dan al-Qur'an) }\end{array}$ \\
\hline Total & 403 \\
\hline
\end{tabular}

Sumber : Olah Data Hasil Kuesioner, 2018

\section{Garis Kontinum Penilaian}

Kesimpulan Penilaian Terhadap Analisa Bauran Pemasaran (Marketing mix) Jasa Penginapan Berbasis Syariah Di Hotel Sofyan Inn Srigunting Bogor.

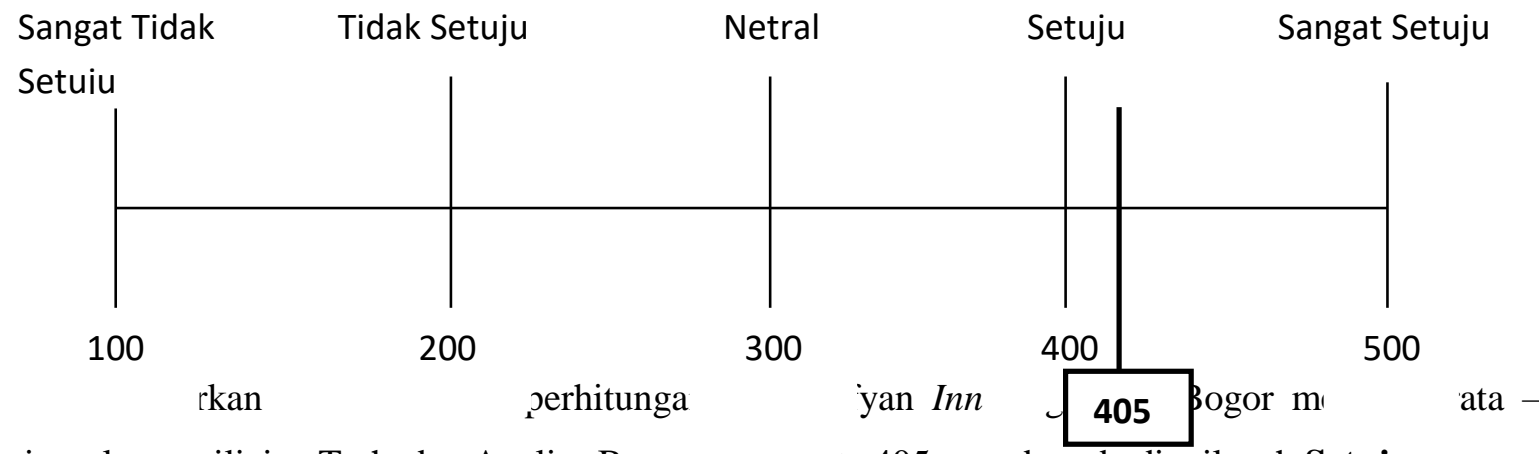

kesimpulan peniliaian Terhadap Analisa Bauran rata 405 yang berada di wilayah Setuju.

Pemasaran (Marketing mix) Jasa Penginapan

Berbasis Syariah yang dilakukan Di Hotel

Pembahasan Hasil Penelitian 
Dari hasil penelitian yang dilakukan oleh penulis tentang Penerapan Analisa Bauran Pemasaran (Marketing mix) Jasa Penginapan Berbasis Syariah di Sofyan Inn Bogor bahwa yaitu pada variabel Phisycal Efiedence memperoleh nilai tertinggi tepatnya pada point "Hotel syariah menyediakan fasilitas lengkap, Room, Meeting room, (Tv, minibar, Internet, water heater) dan perlengkapan ibadah (mukena dan al-Qur'an)" dengan nilai 444 yang termasuk dalam skala sikap “ Setuju” artinya Analisa Bauran Pemasaran (Marketing mix) Jasa Syariah yang di lakukan di hotel Sofyan Inn Srigunting Bogor khususnya di wilayah Phisycal Efiedence dapat dilaksanakan dengan baik.

Nilai terendah yang didapatkan dari variabel produk tepatnya pada point "Hotel syariah menyediakan berbagai tipe kamar yang sesuai dengan kebutuhan" adalah 381 yang termasuk dalam skala sikap "Setuju", artinya strategi pemasaran syariah dapat menyediakan berbagai tipe kamar sesuai kebutuhan meski perlu adanya perbaikan.

Nilai rata - rata terhadap penilaian Analisa Bauran Pemasaran (Marketing mix) Jasa Penginapan Berbasis Syariah di Sofyan Inn Srigunting Bogor adalah diangka 405 yang termasuk dalam skala sikap "Setuju ", yang artinya penerapan Analisa Bauran Pemasaran (Marketing mix) Jasa Penginapan Berbasis Syariah cukup baik dan berhasil.

Manajemen Hotel Sofyan Inn Srigunting Bogor selalu berusaha agar semua karyawan yang terkait dapat memberikan pelayanan sesuai dengan sesuai konsep syariah. Jika terdapat nilai yang rendah maka hal tersebut harus segera diatasi dengan segera.

Sofyan Inn Srigunting Bogor telah mengupayakan untuk menjalankan Pemasaran Jasa Penginapan Berbasis Syariah dengan cukup baik, walaupun meski masih banyak yang harus di perbaiki.

\section{PENUTUP}

\section{Simpulan}

Dari hasil penelitian mengenai analisa Bauran Pemasaran 7p (Marketing mix) Jasa Penginapan Berbasis Syariah di hotel Sofyan Inn Srigunting Bogor yang telah di lakukan, peneliti menemukan hasil sebagai berikut:

1. Variable product (produk) tidak berbengaruh terhadap kepuasan pelanggan. Berdasarkan hasil kuesioner yang disebarkan kepada 100 responden masih terdapat skor kecil hal tersebut dapat dilihat bahwa Hotel syariah menyediakan berbagai tipe kamar hanya mendapatkan skor 381 masuk skala sikap "Setuju" sedangkan produk lainnya sudah cukup baik Sehingga sebagian pelanggan merasa produk hotel Sofyan Inn Srigunting Bogor tidak berpengaruh terhadap kepuasan pelanggan.

2. Variable price (harga) tidak berbengaruh terhadap kepuasan pelanggan. Berdasarkan hasil kuesioner yang disebarkan kepada 100 responden di hotel Sofyan Inn Srigunting Bogor pada poin" Harga hotel syariah sesuai dengan pelayanan dan fasilitas yang 
didapatkan dengan skor 395 masuk skala sikap "Setuju" sedangkan poin kedua harga hotel syariah dapat bersaing dengan hotel konvensional mendapatkan skor 386 masuk skala sikap "Setuju" sehingga hal tersebut sebagian pengunjung merasa harga tidak berpengaruh terhadap apa yang di sediakan oleh hotel Sofyan Inn Srigunting bogor.

3. Variable place (tempat) yang terdapat di hotel Sofyan Inn Srigunting Bogor, cukup strategis seperti dapat dilihat pada poin" Hotel syariah terletak di tempat yang strategis di kota Bogor mendapatkan skor 397 masuk skala sikap "Setuju" dan poin kedua Hotel syariah mudah di akses dengan transportasi umum mendapatkan skor 400 masuk skala sikap "Setuju" kemudahan pelanggan tentang tempat atau akses Hotel Sofyan Inn Srigunting bogor cukup strategis di kota bogor sehingga sebagian pengunjung merasa bahwa hotel Sofyan Inn Srigunting bogor berpengaruh terhadap pilihan pengunjung.

4. Variable Promotion (promosi) yang di berikan oleh hotel Sofyan Inn Srigunting Bogor cukup berpengaruh membantu kemudahan pelanggan untuk mencari dan melihat promo yang ada di hotel Sofyan Inn Srigunting Bogor seperti dapat dilihat pada poin" Hotel syariah sangat mudah di temukan di internet dan website mendapatkan skor 405 masuk skala sikap "Setuju" dan poin kedua Hotel syariah mempromosikan produknya dikemas dengan menarik dan mudah dipahami mendapatkan skor 407 masuk skala sikap
"Setuju" kemudahan pelanggan untuk menemukan hotel dan mendapatkan promo akses Hotel Sofyan Inn Srigunting bogor cukup strategis di kota bogor sehingga memberikan kemudahan untuk para pengunjung yang akan menginap di Hotel Sofyan Inn Srigunting bogor.

5. Variable People (orang) yang ada di hotel Sofyan Inn Srigunting Bogor dapat memberikan nilai kesopanan dan perbedaan yang ada di hotel Sofyan Inn Srigunting Bogor seperti dapat dilihat pada poin" karyawan hotel syariah mengucapkan Assalamualaikum ketika menerima tamu mendapatkan skor 413 masuk skala sikap "Setuju" dan poin kedua karyawan hotel syariah berpenampilan sopan mendapatkan skor 410 masuk skala sikap "Setuju" sehingga pengunjung merasa orang atau karyawan di hotel Sofyan Inn Srigunting bogor berpengaruh terhadap kenyamanan pelanggan yang berkunjung.

6. Variable Process (proses) yang di berikan oleh hotel Sofyan Inn Srigunting Bogor cukup membantu kemudahan pelanggan untuk mencari dan menginap di hotel Sofyan Inn Srigunting Bogor seperti dapat dilihat pada poin" proses pemesanan hotel syariah sangat mudah dan cepat mendapatkan skor 411 masuk skala sikap "Setuju” dan poin kedua proses pembersihan dan persiapan kamar sangat cekatan,sepat dan bersih (clean) mendapatkan skor 416 masuk skala sikap "Setuju" sehingga pengunjung merasa orang 
atau karyawan di hotel Sofyan Inn Srigunting bogor berpengaruh terhadap pelanggan yang akan menginap di hotel Sofyan Inn Srigunting bogor.

7. Variable Phsycal Evidence (fasilitas fisik) yang di berikan oleh hotel Sofyan Inn Srigunting Bogor memiliki untuk mencari dan menginap di hotel Sofyan Inn Srigunting Bogor seperti dapat dilihat pada poin" proses pemesanan hotel syariah sangat mudah dan cepat mendapatkan skor 411 masuk skala sikap "Setuju" dan poin kedua proses pembersihan dan persiapan kamar sangat cekatan,sepat dan bersih (clean) mendapatkan skor 416 masuk skala sikap "Setuju" sehingga pengunjung merasa bahwa bangunan dan suasana di hotel Sofyan Inn Srigunting bogor berpengaruh terhadap kepuasaan dan kenyamanan pelanggan yang akan menginap di hotel Sofyan Inn Srigunting bogor.

\section{Saran}

Dari hasil penelitian yang telah dilakukan penulis,penelitian ini memiliki ketidak pengaruhan sebagai variabel marketing mix terhadap kepuasan pelanggan, variabel yang memiliki ketidak pengaruhan tersebut yang nantinya bisa menjadi saran untuk Hotel Sofyan Inn Srigunting Bogor, yakni:

1. Dari hasil yang diolah melalui kuesioner pada bab sebelumnya terdapat nilai yang kecil pada variabel produk, yaitu hotel Sofyan Inn Srigunting Bogor belum memiliki varian/tipe kamar yang banyak dan yang sesuai dengan kebutuhan pelanggan, maka untuk itu pihak hotel seharusnya mengupgrade fasilitas khususnya menambah jumlah maupun varian/tipe kamar agar dapat memenuhi kebutuhan dan kepuasan tamu.

2. Pada variabel Harga hotel Sofyan Inn Srigunting Bogor masih cenderung sama dengan hotel konvensional dan sesuai dengan fasilitas yang didapatkan.

3. Bauran pemasaran di hotel Sofyan Inn Srigunting Bogor yang meliputi citra hotel, proses layanan pelanggan, lokasi hotel adalah aspek yang sangat dominan dalam penilaiaan para tamu untuk itu perlu dipertahankan dan diharapkan hotel syariah untuk mampu meningkatkannya.

4. Pemerintah dapat mendukung dan diharapkan dapat memanfaatkan jumlah wisatawan muslim untuk mengembangkan potensi hotel syariah Sofyan Inn Srigunting Bogor khususnya di kota Bogor.

5. Kegiatan promosi yang dilakukan hotel syariah perlu ditingkatkan untuk menarik wisatawan terutama wisatawan muslim, untuk menginap di hotel tersebut. Tujuan dilakukannya kegiatan promosi untuk memperkenalkan hotel syariah khususnya dalam penelitian ini yaitu hotel Sofyan Inn Srigunting Bogor sebagai hotel yang menjunjung tinggi nilai Islami.

6. Pengembangan bisnis jasa khususnya industri perhotelan dalam perspektif islam 
yang menerapkan prinsip syariah dapat dijadikan bahan penelitian selanjutnya.

\section{DAFTAR PUSTAKA}

American Marketing Association. 2008. The American Marketing Association Releases New Definition for Marketing. Ama.org

Amstrong, G \& Kotler P. 1997, Prinsip-prinsip pemasaran, cetakan pertama Jakarta: Erlangga .

Arikunto, Suharsimi. 2006. Prosedur Suatu Pendekatan Praktek. Rineka Cipta : Jakarta

Assael. 1992. Consumer Behavior. Edisi Bahasa Indonesia. New Jersey: Prentice Hall Inc. Badan Perencanaan Daerah Kota Bogor. 2010. Master Plan Pariwisata Kota Bogor Tahun $2010 \quad$ (Rencana Induk Pengembangan Pariwisata Daerah Kota Bogor Tahun 2010-RIPPDA). Badan Perencanaan Daerah (BAPEDA) Kota Bogor. Bogor

Boham dan Suwithi. (2008). Akomodasi Perhotelan Jilid I. Direktorat: Pembinaan Sekolah Menengah Kejuruan.

BPS, 2010. mencatat tentang terjadi kenaikan jumlah kedatangan wisatawan, Jakarta indonesia

Departement Pendindikan Nasional (2008). Kamus Besar Bahasa Indonesia Pusat
Bahasa. Jakarta PT.Gramedia Pustaka Utama

Dewan Syariah Nasional (DSN-MUI) dalam Team DSN-MUI, Kumpulan FatwaFatwa DSN MUI 2015.

Dinar Standard and Crescentrating LLC. 2012.Global Muslim Lifestyle Travel Market 2012: Landscape \& Consumer Needs Study For Airlines, Destinations \& Hotels/Resorts.

Engel, James F., Blackwell, Roger D. \& Miniard, Paul W. (1996). Perilaku Konsumen. Alih Bahasa: F. X. Budiyanto, Jilid II, Binarupa Aksara, Jakarta.

Jogiyanto. 2008. Metodologi Penelitian Sistem Informasi. CV Andi Offset. Yogyakarta

Kementerian Pariwisata dan Ekonomi Kreatif. 2012. Kriteria dan Panduan Umum Pariwisata Syariah. Indonesia

Kotler Philip, 1992, Manjemen Pemasaran, edisi kedelapan, Salemba Empat.

Kotler Philip, (1997), Manajemen Pemasaran, Analisis Perencanaan dan Pengendalian, Jilid 2 Edisi Kedelapan, Penerbit Erlangga, Jakarta.

Kotler, Philip, (2000), Manajemen Pemasaran,PT. Prenhallindo, Jakarta

Kotler Philip dan Armstrong Gary.Prinsip Pemasaran.2001.Jakarta;Erlangga

Leedy, (1997), "Practical Research: Planing and Design”, Merrill-Prentice Hall, New Jersey 
Lovelock, Christopher H.,(1991),Service Marketing,2nd edition, Prentice Hall

Monroe, Allard C.R Van Riel et al. (2005). Marketing Antecedent of Industrial Brand Equity: An Empirical Investigation in Specialty Chemical. Industrial Marketing Management (12) 841-847.

Pusat Pengkajian dan pengembangan Ekonomi Islam (P3EI) UII. 2008. Ekonomi Islam. PT Rajagrafindo Persada. Jakarta

Rezeki, S. Reza Irwansyah. 2011. Strategi Komunikasi "Change Management" (Studi Kasus : Perubahan Konsep Bisnis Dari Hotel Konvensional Ke Hotel Syariah). Jurnal Semai Komunikasi Vol. II No. 1. Hal 60-81.

Riyanto Sofyan, Bisnis Syariah Mengapa Tidak? Pengalaman Penerapan Pada Bisnis Hotel, Jakarta: Gramedia Pustaka Utama, 2011.

Rumekso. 2009. Housekeeping Hotel Public Area. Yogyakarta: Andi

Sabri, Fahruddin Ali. 2010. Perkembangan Hotel Syari'ah Di Indonesia; Mengonsep Pariwisata Islami. Karsa, Vol. XVIII No. 2 Oktober 2010, Hal 114-122.

Schiffman, Leon $\mathrm{G}$ and Leslie Lazar Kanuk. (2001). Consumer Behavior.Seven Edition. New Jersey: Prentice Hall, Inc Sihite, Richard. S.Sos, Sales and Marketing (Usaha Pemasaran Hotel) - Ed. 5, Cet. 5 , Surabaya.
Surat Keputusan Menteri Perhubungan No. 241/11/1970. Definisi Hotel

Peraturan Mentri Parawisata (2013).

Surat Keputusan Menteri Perhubungan No. 241/11/1970. Definisi Hotel

Swasta, Basu dan Handoko, Hani. 2001. Manajemen Pemasaran Analisis Perilaku Konsumen. Yogyakarta: BPFE.

William J. Stanton. Prinsip Pemasaran.1984.Jakarta;Erlangga

Yuswohady. (2014). Marketing Of The Middle Class Muslim. Jakarta: Gramedia Pustaka Utama.

Website :

http://www.landasanteori.com/2015/07/pengerti an-pemasaran-menurut-definisi.html (di browsing tanggal 23 July 2017/17.30 WIB)

mb.ipb.ac.id/2015/04/17/konsep-7p-productplace-price-promotion-process-physicalenvironment-people-industri-kosmetikestee-lauder-majalah-hearst-magazine ( di browsing tanggal 23 July 2017/17.31 $\underline{\text { WIB) }}$

http://tiaramayta.blogspot.co.id/2017/

(di browsing tanggal 23 July 2017/17.32 WIB)

repository.uinjkt.ac.id/dspace/handle/12345678 9/34412

(di browsing tanggal 23 July 2017/17.33 WIB)

www.ekomarwanto.com/.../marketing-mix-7pproduk-price-promo 
( di browsing tanggal 23 July 2017/17.34

WIB)

https://soebagia.wordpress.com/.../definisi-arisales-and-marketing

(di browsing tanggal 23 july $2017 / 17.35$ $\underline{\text { WIB) }}$

http://eprints.ums.ac.id/52682/8/daftar\%20pust aka\%20selesai.pdf

( di browsing tanggal 23 july 2017 / 17.36 WIB)

http://repository.upi.edu/19420/9/S_MPP_0908 879_Bibliography.pdf

(di browsing tanggal 23 juli $2017 / 17.37$ $\underline{\text { WIB) }}$

Anonim, 2015. 'LPPOM MUI | Direktori Halal Online'. URL: http://produk.halal.or.id/ (di browsing tanggal 23 juli 2017 / 17.37 WIB)

UNWTO.2013. UNWTO Tourism Highlights 2012 Edition. World Tourism Organization(UNWTO). www.unwto.org 